\title{
JG|U
}

Gutenberg School of Management and Economics \& Research Unit "Interdisciplinary Public Policy" Discussion Paper Series

\section{Producer Services and the Current Account}

\author{
Tobias Gruhle, Philipp Harms
}

May 04, 2019

\section{Discussion paper number 1906}


Contact details

Tobias Gruhle

Chair of International Economics

Johannes Gutenberg University Mainz

Jakob-Welder-Weg 455128

Mainz Germany

tobias.gruhle@uni-mainz.de

Philipp Harms

Chair of International Economics

Johannes Gutenberg University Mainz

Jakob-Welder-Weg 455128

Mainz Germany

philipp.harms@uni-mainz.de

All discussion papers can be downloaded from http://wiwi.uni-mainz.de/DP 


\title{
Producer Services and the Current Account*
}

\author{
Tobias Gruhle ${ }^{\dagger 1}$ and Philipp Harms ${ }^{\ddagger 2}$ \\ 1,2 Johannes Gutenberg University Mainz, Germany
}

This Version: May 4, 2019

\begin{abstract}
In this paper, we present evidence that countries with a higher share of services in GDP exhibit lower current account balances. We argue that this relationship is compatible with the notion that producer services raise aggregate productivity by enhancing increasing returns to specialization, and we develop a model in which the deregulation of the services industry results in higher GDP growth, a reallocation of resources into the services industry, and a temporary current account deficit. We demonstrate that our theoretical argument is supported by the data, even if we control for a multitude of other factors that potentially affect the current account. Finally, we relate our study to the IMF's external balance assessment (EBA) exercise and demonstrate that, for several countries, the "current account gap" shrinks if we account for producer services.
\end{abstract}

Keywords: International macroeconomics, current account, producer services.

JEL Classification: F41, O14, F32.

${ }^{*}$ This paper has benefited from helpful comments by Tobias Krahnke, Laura Schmidt, Philip Sauré, Klaus Wälde, Jean Roch Donsimoni and the participants at the 10th International Sponsoring Congress "Young Science and Business" of the Hanns Martin Schleyer Foundation as well as seminar participants at the Deutsche Bundesbank and at Johannes Gutenberg University Mainz.

† tobias.gruhle@uni-mainz.de

${ }^{\ddagger}$ philipp.harms@uni-mainz.de 


\section{Introduction}

In recent years, the topic of "global imbalances" has been high on the agenda of both policymakers and researchers, and the interpretation of persistent current account surpluses and deficits has ranged from an equilibrium phenomenon to a potential risk for global macroeconomic stability or a symptom of "unfair" policy practices. Of course, whatever assessment one chooses crucially hinges on the factors that one considers to be fundamental drivers of countries' current account balances. ${ }^{1}$

In this paper, we shift the focus to the role of industrial structure, departing from the observation that countries that exhibit a higher share of services in total value added run lower current account balances. Figure 1 plots countries' average service share in gross domestic product (GDP) between 2000 to 2010 against their average current account balance relative to GDP over the same time span. The negative correlation is clearly discernible, and it is still present when we control for other potential determinants of current accounts. ${ }^{2}$ Moreover, as we will demonstrate in later chapters, it is particularly strong for producer services, i.e. those services that are not delivered to final customers, but that are part of other companies' supply chain.

There is, of course a simple explanation for the negative correlation between the services share and countries' current accounts: an exogenous expansion of services reduces the domestic production of tradable goods and thus necessitates larger imports, and this is ultimately reflected by a current account deficit. However, such a "Dutch-disease" type of interpretation does not explain whether and how these deficits are compatible with agents' optimization and their intertemporal budget constraint. We therefore offer an alternative explanation that emphasizes the productive role of services. We develop a two-sector model of a small open economy, in which labor is either employed in the (manufacturing) final-goods sector or by services firms whose output is used as an intermediate input in final-goods production. A stronger presence of producer services raises aggregate productivity, since specific tasks that were previously performed by manufacturing companies themselves are outsourced to firms that are able to realize gains from specializing in these tasks. ${ }^{3}$

We analyze the effect of a deregulation in the services industry - modeled as a reduction in service firms' fixed costs - and show that it results in a contraction of manufacturing employment, an expansion of services employment, and increasing final goods output. We assume that, due to network externalities, the current expansion of the services sector facilitates the emergence of additional firms in the future. This, in turn, gives rise to growth expectations that reduce savings and are reflected by current account deficits.

Endowed with the hypothesis that an expansion of producer services lowers a country's current account balance, we turn to the data, using the framework employed by the IMF in its external balance assessment (EBA). We demonstrate that, ceteris paribus, the share of producer services in GDP has a negative effect on the current account, and that the inclusion of this variable contributes to the explanatory power of the model. Moreover, we provide evidence that the negative effect of producer services on the current account hinges

\footnotetext{
${ }^{1}$ Empirical analyses that identify the determinants of current account balances are provided by Chinn and Prasad (2003), Chinn and Ito (2008a), and - in the context of the IMF's external balance assessment (EBA) - by Phillips et al. (2013).

${ }^{2}$ This negative relationship can also be found between countries' current account balances and the employment share of services.

${ }^{3}$ Examples of such processes are companies that outsource their IT departments to external providers, or companies that delegate the organization of logistics to specialized contractors.
} 
Figure 1: Service Shares and Current Accounts

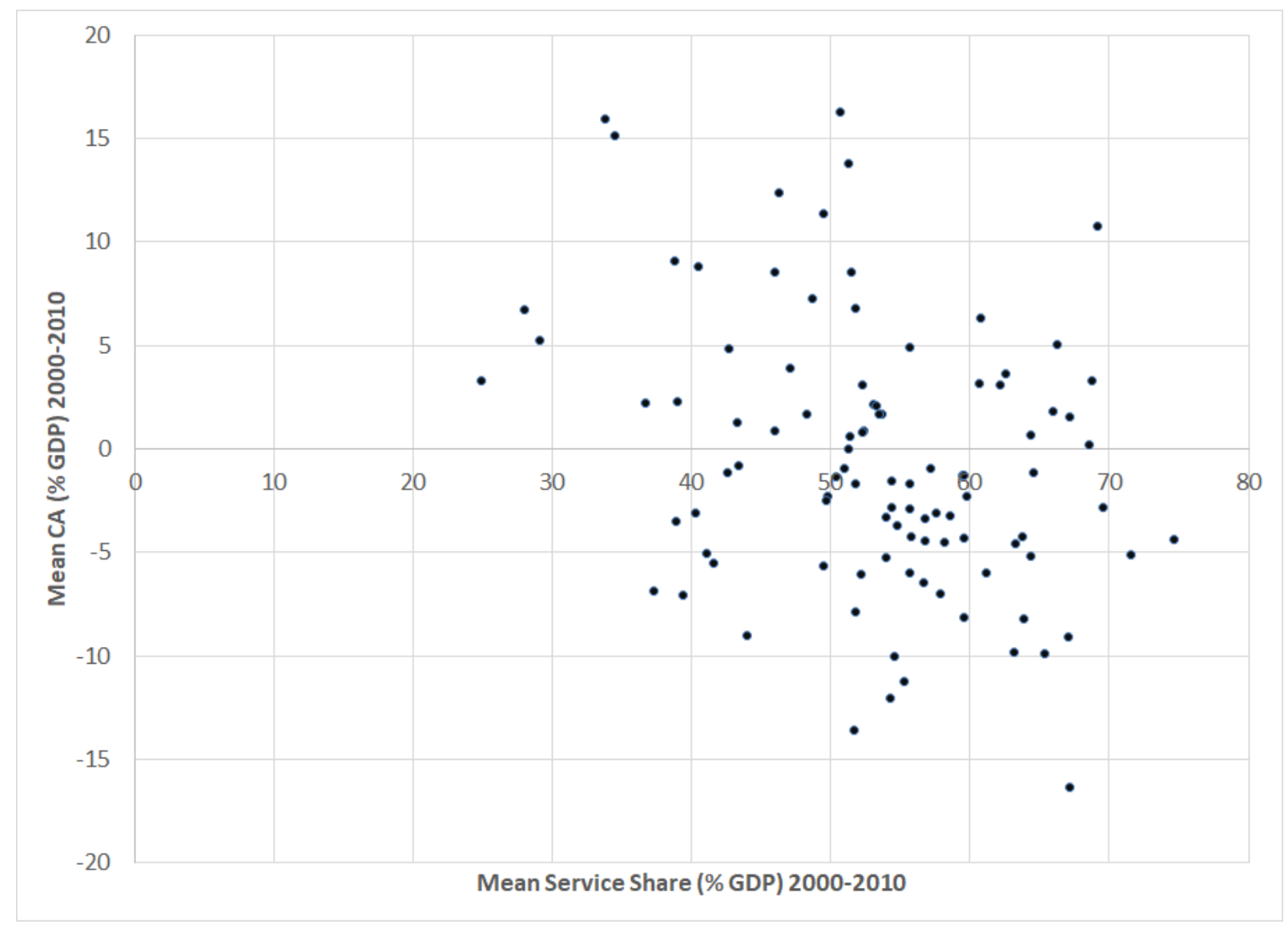

Source: World Development Indicators. 61 Middle income and 38 High Income Countries.

on an increasing extent of outsourcing. Finally, we show that current account gaps decrease for several countries if we explicitly account for the role of services as a potential determinant of current accounts.

The rest of the paper is structured as follows. Section 2 reviews the relevant literature. Section 3 presents a model that analyzes the role of producer services in a two-sector open economy. In section 4, we present our empirical analysis and include different measures of countries' industrial structure in the IMF's external balance assessment (EBA). Section 5 offers a summary and some conclusions.

\section{Literature Review}

The first group of contributions our analysis is related to considers the consequences of productivity growth for the current account. Bracke et al. (2010) provide a recent overview of the structural and cyclical drivers of external imbalances, and list persistent productivity shocks as a possible explanation for external imbalances. Hunt and Rebucci (2005) use a model with tradable and nontradable goods to analyze the effects of temporary and permanent productivity shocks on the real exchange rate and the trade balance. After calibrating their model, they find that the evolution of the US external position can largely be explained by a shock to productivity but, additionally, by agents' learning and a shock to portfolio preferences. A similar result is derived by Bems et al. (2007) who estimate the effects of three different shocks on the US econ- 
omy, and study the consequences for the current account. The shocks are a productivity shock and shocks to monetary and fiscal policy. The authors find that a shock to productivity can help to explain shifts in the external balance, which is in line with the theory of a future increase in income resulting in an increase of consumption and investment. Shocks to productivity are also at the heart of the study by Hoffmann et al. (2017) who propose that changes in productivity-growth expectations are responsible for movements of the U.S. current account. As the growth of productivity can only be observed with noise, it takes some time before a permanent shock to the growth trend is fully included in agents' expectations. The authors find the saving glut hypothesis, as proposed by Bernanke et al. (2005) and Bernanke et al. (2007), to be less relevant for the current account of the US. Empirically this result is also confirmed by Amdur and Kiziler (2014).

The second group of contributions that are relevant in our context studies the link between countries' industrial structure and productivity growth. In a recent paper, Oulton (2016) observes that, in most countries, there is a shift of resources into industries with lower growth rates of total factor productivity (TFP) - mainly from manufacturing and agriculture into business services. The author argues that, nevertheless, the observed structural change does not necessarily reduce an economy's productivity growth, provided the economy shifts its resources into an intermediate sector with a non-negative productivity growth rate. Oulton identifies business services as such a sector, and he presents some evidence that this kind of structural change raises aggregate TFP in some economies. Benigno and Fornaro (2014) also focus on the relationship between countries' industrial structure and their productivity growth and propose an open-economy model that incorporates structural change. They see the tradable (or manufacturing) sector as a driver of productivity growth, as this sector allows absorbing foreign knowledge. In such an environment, access to cheap capital - designated as the financial resource curse by the authors - can result in a shift of the economy towards the sector of nontradable goods or services, similar to the Dutch disease explained by Corden and Neary (1982). As a result, the economy will exhibit slower growth, due to the lower share of the productivity-increasing manufacturing sector, and it will run a current account deficit. Crucial for this result is the assumption of the manufacturing sector being productivity-increasing while the service sector drags down productivity growth. However, this perspective is not in line with evidence presented by Timmer et al. (2011) and Oulton (2016).

The third group of contributions related to our study focuses on the link between an economy's industrial structure and its current account. Benigno et al. (2015) consider a sample of 70 countries over 35 years and find that episodes of capital inflows are often accompanied by an expansion of the non-tradable goods sector - mainly services - in the respective economy. Once capital flows recede, an economy experiences lower productivity growth, except for capital inflow episodes that take place in times of abundant global liquidity. Another important contribution on the link between industrial structure and the current account is offered by Jin (2012). Jin combines the classical perspective on capital flowing to places where it is scarce with a perspective that emphasizes that capital is flowing towards the place where it is easier to install. In her multi-sector OLG model, she uses the standard notion that adjustment costs decrease in the level of the capital stock and shows that capital may flow to economies that are already heavily engaged in the production of capital-intensive goods. ${ }^{4}$ Finally, Barattieri (2014) finds that countries specializing in the export of services tend to display current account deficits. Observing that the liberalization of services trade is lagging behind the liberalization of goods trade, he argues that countries with a comparative advantage

\footnotetext{
${ }^{4}$ Note that the mechanism proposed by Jin contradicts the observation of capital flowing to economies with a higher share of services - unless, of course, the production of services is very capital-intensive.
} 
in services run current-account deficits now in expectation of a future increase in profits, resulting from an expected expansion of services trade.

The key contribution of our paper to these various strands of literature is to emphasize the productivityenhancing effect of an expanding services sector, and to link this effect to the evolution of a countries' current accounts.

\section{A Model of Producer Services, Growth, and the Current Account}

\subsection{Final Goods Production}

We consider a small open economy that consists of a final goods sector and a producer services sector. The final goods sector produces output $Y_{t}$ and operates under perfect competition. The final good can be freely traded internationally, and it is used as the numéraire of our model, i.e. its price is set to unity for every period. The technology used by the final goods industry at time $t$ is described by the following production function:

$$
Y_{t}=A_{t}\left[\alpha\left(L_{t}^{Y}\right)^{\gamma}+(1-\alpha)\left(X_{t}\right)^{\gamma}\right]^{\frac{1}{\gamma}} \text { with } \alpha \in(0,1), \gamma \in(0,1)
$$

In (1), $L_{t}^{Y}$ denotes the amount of labor employed by the representative final-goods firm, whereas $X_{t}$ represents a bundle of tasks which the representative final-goods firm delegates to suppliers of producer services, and which we treat as a bundle of intermediate inputs. Moreover, $A_{t}$ is total factor productivity, and $\gamma$ determines the (constant) elasticity of substitution $1 /(1-\gamma)$ between labor employed in the final goods industry and producer services. Our assumption that $\gamma \in(0,1)$ reflects the idea that it is not too hard to substitute producer services $X_{t}$ for in-house employment $L_{t}^{Y}$ in the final-goods industry. The bundle of producer services used in final goods-production is represented by the following function:

$$
X_{t}=\left(\sum_{i=1}^{N_{t}}\left(x_{i t}\right)^{\theta}\right)^{\frac{1}{\theta}} \text { with } \theta \in(0,1)
$$

where $\theta$ determines the elasticity of substitution $1 /(1-\theta)$ between individual service types. As in the seminal papers by Ethier (1982), Romer (1987) and Romer (1990), this function captures the idea of increasing returns to specialization: suppose that $x_{i t}=x_{t}$ for all $i$ and that $x_{t}=Q_{t} / N_{t}$ with $Q_{t}>0$. It is easy to show that, in this case, $X_{t}=N_{t}^{\frac{1-\theta}{\theta}} Q_{t}$, i.e. spreading a given volume of resources $Q_{t}$ across a larger number of intermediate goods $N_{t}$ raises output $X_{t}$. We will later show how a deregulation of the producer services sector raises the (endogenous) number of firms $N_{t}$, and how the availability of an increasing number of differentiated producer services enhances growth. 
The price index for the total bundle of producer services in period $t$ is given by

$$
P_{t}^{X}=\left(\sum_{i=1}^{N_{t}}\left(p_{i t}\right)^{\frac{\theta}{\theta-1}}\right)^{\frac{\theta-1}{\theta}}
$$

Perfect competition in the final-goods sector implies the following relationships, which implicitly define firms' optimal demand for individual producer services and labor, respectively:

$$
\begin{gathered}
p_{i t}=\frac{(1-\alpha) Y_{t}\left(X_{t}\right)^{(\gamma-\theta)}}{\left[\alpha\left(L_{t}^{Y}\right)^{\gamma}+(1-\alpha)\left(X_{t}\right)^{\gamma}\right]}\left(x_{i t}\right)^{\theta-1} \\
w_{t}=\frac{\alpha Y_{t}\left(L_{t}^{Y}\right)^{(\gamma-1)}}{\left[\alpha\left(L_{t}^{Y}\right)^{\gamma}+(1-\alpha)\left(X_{t}\right)^{\gamma}\right]}
\end{gathered}
$$

In (4) and (5), $p_{i t}$ is the price of producer service $i$, and $w_{t}$ is the wage rate at time $t$. Combining (3) and (4), we can show that the demand for the total bundle of producer services is implicitly defined by the following expression:

$$
P_{t}^{X}=\frac{(1-\alpha) Y_{t}\left(X_{t}\right)^{(\gamma-1)}}{\left[\alpha\left(L_{t}^{Y}\right)^{\gamma}+(1-\alpha)\left(X_{t}\right)^{\gamma}\right]}
$$

Due to perfect competition, profits in the final goods sector are zero in all periods i.e.

$$
\Pi_{t}^{Y}=Y_{t}-w_{t} L_{t}^{Y}-P_{t}^{X} X_{t}=0
$$

Combining this fact with the above expressions, it is easy to show that $Y_{t}=w_{t} L$, where $L$ represents the economy's total labor endowment. Hence, the total revenue of the final goods sector equals total labor income, which, in turn, equals the economy's GDP.

\subsection{The Services Sector}

The services sector is characterized by monopolistic competition, with every firm supplying a specific service to final-goods firms. At time $t$, service provider $i$ uses the labor input $L_{i t}^{X}$ to produce the amount $x_{i t}$, 
using the following technology

$$
x_{i t}=\max \left[a_{t} X_{t-1}^{\rho}\left(L_{i t}^{X}-\kappa_{t}\right), 0\right], \text { with } \rho \in(0,1), a_{t}>0
$$

In (8), $\kappa_{t}$ is the fixed amount of labor input that is necessary for any service provider to generate positive output, $a_{t}$ is a productivity parameter, and $X_{t-1}^{\rho}$ is the aggregate service output of the preceding period. By making the productivity of individual service providers dependent on aggregate service output, we assume the existence of network externalities, as suggested by Francois and Hoekman (2010). These network externalities are the stronger, the higher the current value of intermediate services. At the same time, firms need time to adjust to a changing environment, and the effect of aggregate service output thus also decreases in the change of $X_{t}$, i.e. $\Delta X_{t} \equiv X_{t}-X_{t-1}$. A general version of (8) would read $x_{i t}=$ $\max \left[a_{t} f\left(X_{t}, \Delta X_{t}\right)^{\rho}\left(L_{i t}^{X}-\kappa_{t}\right), 0\right]$, with the function $f$ increasing in $X_{t}$ and decreasing in $\Delta X_{t}$. For the sake of simplicity, we assume that $f\left(X_{t}, \Delta X_{t}\right)=X_{t}-\Delta X_{t}$, which simplifies to $f\left(X_{t}, \Delta X_{t}\right)=X_{t-1}$. Finally, the assumption that $\rho<1$ is meant to capture the idea that network externalities are subject to diminishing returns.

Given service firms' monopoly position and the demand function (4), it is easy to show that a service provider $i$ charges the optimal price

$$
p_{i t}=\frac{w_{t}}{a_{t} X_{t-1}^{\rho}} \frac{1}{\theta}
$$

where $\frac{1}{\theta}>1$ is the firm's markup over marginal cost.

In every period $t$, there is free entry of firms into the services sector. This implies that, in equilibrium, profits equal zero. Using (8), (9), and imposing the zero-profit condition, we can derive the amount of labor employed by an individual firm in equilibrium:

$$
L_{i t}^{X}=\frac{\kappa_{t}}{1-\theta}
$$

Substituting this expression into the production function (8) yields the output of a representative service firm:

$$
x_{i t}=a_{t} X_{t-1}^{\rho} \kappa_{t}\left(\frac{\theta}{1-\theta}\right)
$$

This expression has a straightforward interpretation: the firm's output increases in total factor productivity $a_{t}$ and the strength of network externalities $X_{t-1}^{\rho}$, since both reduce a firm's marginal costs. Equilibrium 
output also increases in the level of fixed costs, since a higher value of $\kappa_{t}$ necessitates a larger volume of production in order to prevent negative profits. Finally, the equilibrium value of $x_{i t}$ increases in the elasticity of substitution among producer services $1 /(1-\theta)$ since a higher elasticity reduces the markup and forces a firm to produce large amounts in order to cover its fixed costs.

\subsection{Consumers}

The representative consumer maximizes her utility over an infinite time horizon, i.e.

$$
U_{t}=\sum_{s=t}^{\infty} \beta^{s-t} u\left(C_{s}\right)
$$

where $u\left(C_{s}\right)$ is a per-period utility function that satisfies the standard properties, and where $\beta \in(0,1)$ is the consumer's subjective discount factor. In any period $s$ the consumer faces the flow budget constraint

$$
C_{s}+B_{s+1}=(1+r) B_{s}+w_{s} L
$$

where $B_{s}$ is the net international investment position of the economy at the beginning of period $s$, and $r$ the risk-free return offered by the international capital market. The current account is given by $C A_{s}=$ $B_{s+1}-B_{s}$. Solving the utility maximization problem of the consumer results in the intertemporal Euler condition

$$
u^{\prime}\left(C_{s}\right)=[\beta(1+r)] u^{\prime}\left(C_{s+1}\right) \quad \forall s \geq t
$$

Combined with the usual no-Ponzi condition, this determines the representative consumer's optimal consumption path. For simplicity, we assume that $\beta(1+r)=1$. This implies that $C_{s+1}=C_{s}$ for all $s$, i.e. intertemporal optimization implies a constant consumption level.

\subsection{Equilibrium}

The economy is endowed with a fixed amount of labor $L$, which is perfectly mobile across sectors and firms. The labor market clearing condition is

$$
L=L_{t}^{Y}+N_{t} L_{i t}^{X}
$$


where $L_{i t}^{X}$ is given by (10) and $N_{t}$ is the (endogenous) number of producer services firms. Due to our symmetry assumption, we can write $L_{i t}^{X}=\bar{L}_{t}^{X} \forall i$. Accounting for the fact that $Y_{t}=w_{t} L$ and using equation (5), we can derive an expression that implicitly defines the amount of labor employed in final goods production:

$$
\frac{L_{t}^{Y}}{L}=\frac{\alpha\left(L_{t}^{Y}\right)^{\gamma}}{\alpha\left(L_{t}^{Y}\right)^{\gamma}+(1-\alpha)\left(X_{t}\right)^{\gamma}}
$$

with $X_{t}$ determined by (2) and (11).

Combining (10) and the full-employment condition (15), the equilibrium number of firms in the service sector $N_{t}$ can be written as:

$$
N_{t}=\frac{(1-\theta)}{\kappa_{t}}\left(L-L_{t}^{Y}\right)
$$

The labor market equilibrium in the economy is fully characterized by (2), (11), (16) and (17). Furthermore, we can define the employment share of the services sector in the economy as

$$
s_{t}^{\text {ser }}=\frac{N_{t} \bar{L}_{t}^{X}}{L}
$$

which can be shown to equal the value added share of the service sector in the economy's GDP, i.e. $s_{t}^{s e r}=\frac{P_{t}^{X} X_{t}}{Y_{t}}$. The term $\frac{L_{t}^{Y}}{L}=\frac{w_{t} L_{t}^{Y}}{Y_{t}}$ is then the employment share of the final goods sector in the economy, i.e. $\left(1-s_{t}^{s e r}\right)$.

In order to analyze the comparative-static and dynamic properties of the model, we first have to make sure that there is a unique value $L_{t}^{Y} \in(0, L)$ that satisfies equation (16). ${ }^{5}$

In what follows, we focus on the (plausible) case that it is easier to substitute different producer services against each other than to replace in-house employment in the final-goods sector by producer services. This is reflected by the following assumption:

Assumption 1. The elasticity of substitution in the producer-services sector is higher than the elasticity of substitution between in-house employment in final-goods firms and producer services, i.e. $\gamma<\theta$.

Using this assumption, we can show that there is a unique interior equilibrium on the labor market. This is expressed by the following proposition:

\footnotetext{
${ }^{5}$ Of course, equation (16) is also satisfied for the boundary solutions $L_{t}^{Y}=L$ and $L_{t}^{Y}=0$. In the first case, final goods firms do not outsource any tasks, in the second case, they do not keep any in-house employment. It is, however, easy to show that these equilibria are not stable, since the marginal productivity of $L_{t}^{Y}$ is infinite at $L_{t}^{Y}=0$, and the marginal productivity of $X_{t}$ is infinite at $L_{t}^{Y}=L$. Firms thus have an incentive to avoid these boundary solutions.
} 
Figure 2: Equilibrium Employment in the Final-Goods Sector

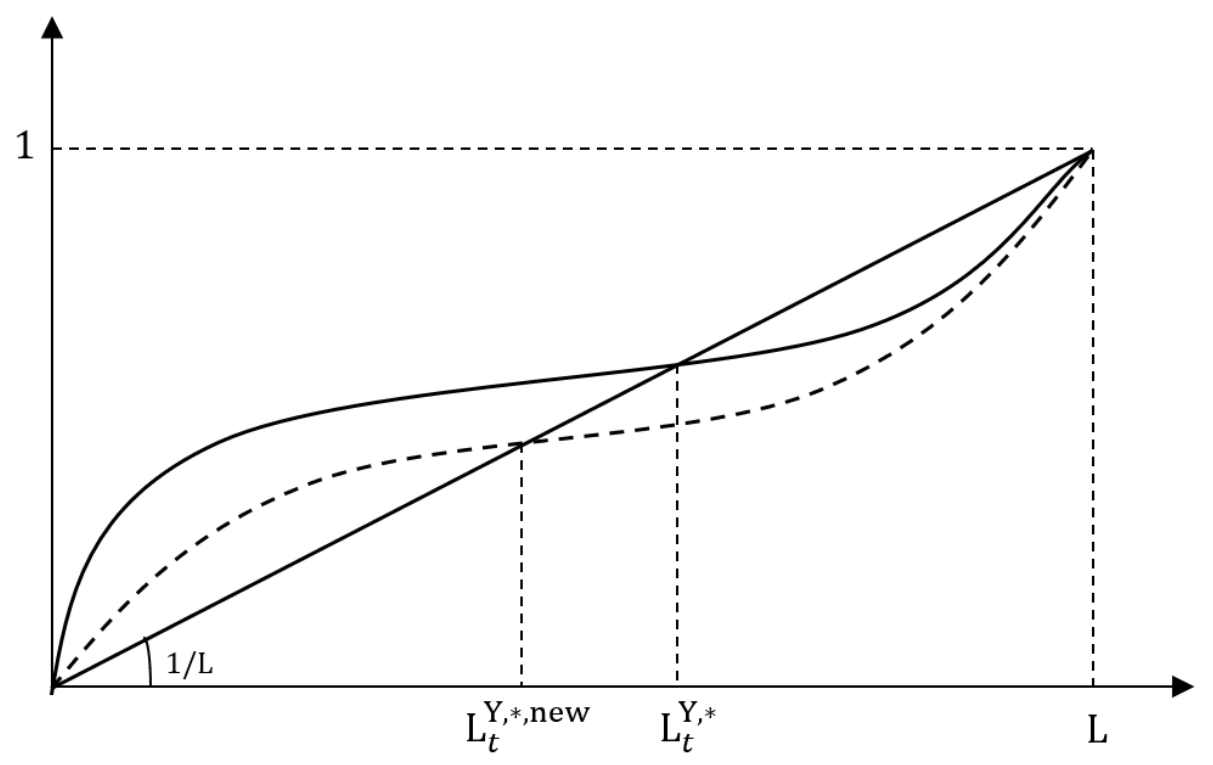

Proposition 1. If $\gamma<\theta$, an interior equilibrium with $0<L_{t}^{Y}<L$ exists and is unique.

Proof: See the Appendix.

The result stated by Proposition 1 is illustrated by Figure 2, where the straight line represents the LHS of equation (16), the curved line represents the RHS of equation (16) - incorporating (2), (11) and and (17) - and $L_{t}^{Y, *}$ the (unique) interior solution.

\subsection{The Short- and Long-Run Effects of Deregulating Producer Services}

In this section, we analyze how a deregulation of the producer services industry affects the economy's sectoral structure, its output in the short and the long run, and the time path of the current account. Deregulation is modeled as a permanent decrease of the fixed cost component $\kappa_{t}$ for producer services firms. We start by demonstrating that lowering $\kappa_{t}$ lowers employment in final-goods firms and raises the share of producer services in total output. This is reflected by the following Lemma:

Lemma 1. A permanent decrease of $\kappa_{t}$ results in an immediate increase of the employment and value added share of the service sector in the economy $\left(s_{t}^{\text {ser }}\right)$.

Proof: See the Appendix

The result of Lemma 1 is visualized in Figure 2. Using equations (2), (11) and (17), the total volume of producer services $\left(X_{t}\right)$ can be written as

$$
X_{t}=(1-\theta)^{\frac{1-\theta}{\theta}} \theta a_{t} X_{t-1}^{\rho} \kappa_{t}^{\frac{\theta-1}{\theta}}\left(L-L_{t}^{Y}\right)^{\left(\frac{1}{\theta}\right)}
$$

For a given value of $L_{t}^{Y}, X_{t}$ obviously decreases in $\kappa_{t}$. Hence the RHS of equation (16) is shifted 
downward by a diminishing value of $\kappa_{t}$. This results in a new point of intersection, which implies a lower equilibrium value $L_{t}^{Y, *, n e w}$.

The result presented in Lemma 1, combined with equation (17), implies that the number of services firms $N_{t}$ increases as a result of a diminishing value of $\kappa_{t}$. Due to increasing returns to specialization, this raises productivity in the producer-services sector. At the same time, employment in the final-goods sector and output of individual services firms decreases (see equation (11)). The following lemma demonstrates that the former effect dominates the latter two, such that final goods output increases as a result of producerservices deregulation:

Lemma 2. A permanent decrease of $\kappa_{t}$ raises final goods output and thus the economy's GDP.

Proof. We have shown above that the economy's GDP equals the value of its final-goods output which, in turn equals the wage sum $w_{t} L$. Since labor supply is constant, variations in GDP are thus driven by variations in $w_{t}$. Using (5), we can write the wage as

$$
w_{t}=A_{t} \alpha\left[\alpha+(1-\alpha)\left(\frac{X_{t}}{L_{t}^{Y}}\right)^{\gamma}\right]^{\frac{1-\gamma}{\gamma}}
$$

As we have seen above, a lower value of $\kappa_{t}$ raises $X_{t}$ and reduces $L_{t}^{Y}$. This, in turn, results in a higher wage and thus a higher GDP level.

Note that the effect of lowering $\kappa_{t}$ on GDP does not result from the fact that the economy spends less resources on fixed costs. In fact, the opposite is the case: Using equation (17), we can show that aggregate fixed costs are given by $N_{t} \kappa_{t}=(1-\theta)\left(L-L_{t}^{Y}\right)$. Since a decreasing value of $\kappa_{t}$ lowers $L_{t}^{Y}$, aggregate fixed costs increase. The positive effect on GDP is thus exclusively driven by increasing returns to specialization, i.e. the fact that a larger number of smaller firms supply a more diverse set of producers services, which raises aggregate productivity of the services sector.

While the previous results referred to the economy's immediate reaction to a lower value of $\kappa_{t}$, the following lemma considers the evolution of GDP over time:

Lemma 3. After a permanent decrease of $\kappa_{t}$, the economy's aggregate income grows for several periods and eventually converges to a higher steady-state level.

Proof. We use the expression for $X_{t}$ from equation (19):

$$
X_{t+1}=(1-\theta)^{\frac{1-\theta}{\theta}} \theta a_{t+1} X_{t}^{\rho} \kappa_{t+1}^{\frac{\theta-1}{\theta}}\left(L-L_{t+1}^{Y}\right)^{\left(\frac{1}{\theta}\right)}
$$

Obviously, a higher value of $X_{t}$ raises $X_{t+1}$. Hence, it has the same qualitative effect as a decreasing value of $\kappa_{t+1}$, and we can use the results stated by previous lemmas. The dynamic relationship between $X_{t}$ and $X_{t+1}$ implies that aggregate services supply and GDP increase even after $\kappa_{t}$ has settled on its new long-run value. However, since $0<\rho<1$, this process eventually slows down, and $X$ converges to its new steady-state level 
Table 1: Simulation - Parameters

\begin{tabular}{|l|c|}
\hline Parameter & Value \\
\hline$\gamma$ & 0.2 \\
$\theta$ & 0.5 \\
$A_{0}$ & 1 \\
$\alpha$ & 0.85 \\
$\rho$ & 0.5 \\
$\beta$ & 0.97 \\
$r$ & $\frac{1}{\beta}-1$ \\
$a_{0}$ & $\frac{2}{3}$ \\
$L$ & 100 \\
$B_{0}$ & 0 \\
$\kappa_{1}$ & 1 \\
$\kappa_{2}$ & 0.99 \\
\hline
\end{tabular}

$X=\left[(1-\theta)^{\frac{1-\theta}{\theta}} \theta a \kappa^{\frac{\theta-1}{\theta}}\left(L-L^{Y}\right)^{\left(\frac{1}{\theta}\right)}\right]^{\frac{1}{1-\rho}}$

where steady-state values are characterized by the omission of time subscripts.

The mechanics behind the result in Lemma 3 are straightforward: the reduction of fixed costs gives a boost to the producer services-sector, raising $X_{t}$. Due to the positive network externalities ingrained in equation (8), this makes it easier to supply producer services in the following period, reinforcing structural change and further raising final goods output. Since $\rho<1$, however, this effect materializes at a decreasing rate, and eventually the economy converges to a higher steady-state level of GDP.

The reaction of the current account reflects the representative consumer's consumption smoothing in anticipation of future income increases. Due to the assumption that $\beta(1+r)=1$, the representative consumer immediately moves consumption to a higher long-run level once she perceives the "deregulation shock". Since she anticipates further income increases in the future, consumption rises by more than income, reducing aggregate savings. This, in turn, results in a current account deficit, which disappears as the economy converges to its new steady state.

To illustrate the effects described above, we ran a numerical simulation of the model economy, based on the parameter values shown in Table 1. The impulse responses depicted in Figure 3 trace the short-run and long-run consequences of a permanent reduction of $\kappa_{t}$, which we interpret as a "deregulation shock", i.e. an improvement of the business environment for producer services firms. The shock is assumed to hit the economy in period 11. Unless stated otherwise, values are indexed at 1 for the steady state before the shock occurs.

The first panel in the first row of Figure 3 demonstrates that, on impact, the volume of output per service firm decreases. This directly follows from equation (11) and reflects the fact that lower fixed costs reduce the volume of output per firm that is compatible with non-negative profits. At the same time, however, the number of producer-services firms - and thus the number of services varieties - increases, which is reflected by the second panel in the first row of Figure 3. The panels in the second row of Figure 3 demonstrate that 
Figure 3: Reducing Fixed Costs in the Services Sector: Impulse Response Functions
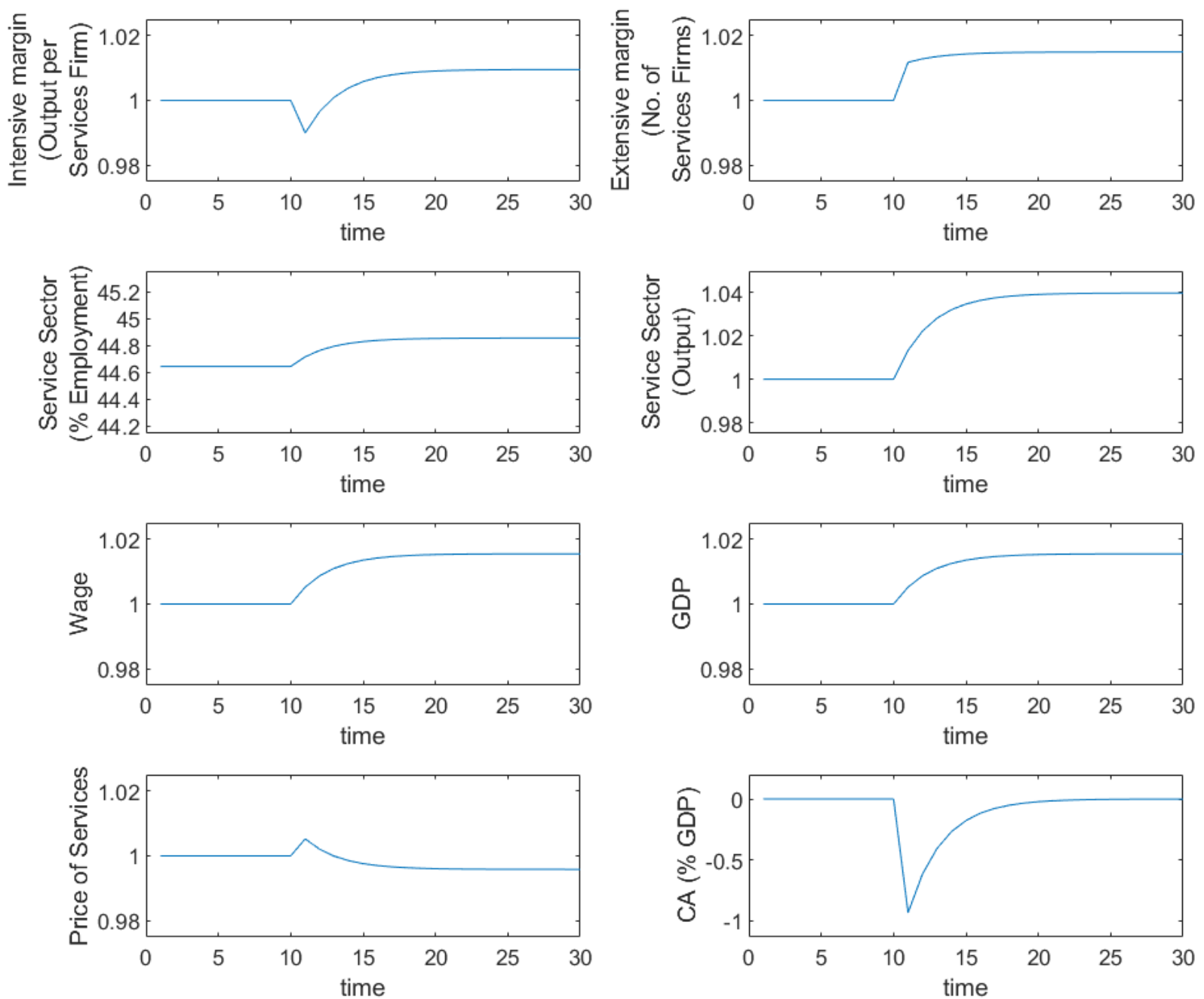
the latter effect dominates the former, i.e. total services employment and output increase on impact. The additional labor demand results in an increase of the economy-wide wage (see the first panel in the third row) and of GDP (see the second panel in the same row). The expansion of $X_{t}$ in the impact period, combined with the positive relationship between $X_{t}$ and $X_{t+1}$ determine the behavior of the economy in subsequent periods: first, the higher value of $X_{t+1}$ lowers marginal costs, which results in a higher output of individual service firms (see the first panel in the first row of Figure 3). Both the number of firms, employment and output in the services sector increase - and so do the wage and GDP. By contrast, the prices set by individual service firms decrease after the original upward jump (see the left panel in the last row). ${ }^{6}$ Since $0<\rho<1$, $X_{t}$ and all other variables eventually converge to their steady-state levels, but during the transition to the new steady state, GDP keeps growing. The anticipated income gains induce the representative consumer to move consumption to a level that exceeds current income on impact, and the resulting decline in savings is reflected by a current account deficit pictured in the right panel in the last row of Figure 3. This deficit disappears as GDP converges to its higher steady state level.

During the transition to the new steady state, we observe a combination of an expanding services sector and higher GDP growth rates. This seems to contradict Baumol (1967) who argues that services offer a limited potential for productivity growth - an idea that is also reflected by the contributions of Benigno and Fornaro (2014), Weber et al. (2017), and IMF (2018). In our model, however, it is not the individual services firm that achieves a higher productivity level. Instead, it is the organization of the production process - more specifically, the increasing returns to specialization associated with the outsourcing of producer services that enhances growth.

\section{Producer Services, Outsourcing and the Current Account: An Empirical Analysis}

\subsection{Adopting the IMF's EBA Framework}

The model of the last section suggested that a deregulation-driven expansion of the services sector depresses the current account balance, since it is related to future income increases and reduces aggregate savings. In this section, we test this hypothesis by adding producer services to the list of potential determinants of the current account. While these determinants have been analyzed by various papers (see, e.g. Obstfeld and Rogoff (1995), Chinn and Prasad (2003), De Santis and Lührmann (2009), Chinn and Ito (2008a), Chinn and Ito (2008b)), we adopt the approach and specification used by the IMF in its external balance assessments (EBA) (see Phillips et al. (2013)). This allows assessing the role and importance of producer services in a framework that is widely used in policy discussions. Moreover, we can use this framework to explore whether the explicit consideration of services contributes to lowering the "current account gaps" identified by the IMF.

In our empirical analysis, we will estimate the parameters of the following equation:

\footnotetext{
${ }^{6}$ The initial upward jump of service prices can be explained by the initial rise in wages, which is only gradually dominated by the productivity gains associated with an expanding services sector and the resulting network externalities.
} 


$$
c a_{c t}=\boldsymbol{\beta}^{\prime} \boldsymbol{x}_{c t}+\boldsymbol{\delta}^{\prime} \boldsymbol{z}_{c t}+\epsilon_{c t}
$$

where $c a_{c t}$ is country $c$ 's current account balance in period $t$, and $\boldsymbol{x}_{c t}$ are variables reflecting an economy's sectoral structure and the prevalence of outsourcing - i.e. proxies for the forces described by our theoretical model. ${ }^{7}$ Inter alia, we will include the share of producer services and the share of consumer services in an economy's value added, as well as interaction terms that capture the extent of outsourcing in sectors associated with final goods production. Finally, $\boldsymbol{z}_{c t}$ is the vector of cyclical, structural and policy variables suggested by the IMF's EBA analysis, and $\epsilon_{c t}$ is the standard error term. ${ }^{8}$

The cyclical variables included in the regression of the EBA-approach and in our estimation are the output gap (Output gap) - i.e. the difference between actual GDP and potential GDP - and the commodity terms of trade interacted with trade openness (Commodity ToT). Including these variables allows controlling for temporary cyclical effects that affect the current account given the annual frequency of the data. As mentioned by Phillips et al. (2013) the expected coefficient of the output gap is negative, reflecting the idea that a higher output gap indicates higher demand and therefore lower savings and more investment. Conversely, the interaction term of the terms of trade with trade openness is expected to have a positive coefficient.

The second group of variables consists structural (or "fundamental") current account determinants. To control for the level of development, we include countries' income level in two ways: first, we use output per worker relative to the three largest economies (Output per worker) in the sample as a measure how close to the development frontier an economy is. The expected effect on the current account is positive, as capital is likely to flow from rich to poor countries. Moreover, we use an interaction term of Output per worker and capital openness (Output per worker \# capital openness), since the degree of financial openness is crucial for capital flows between economies at different stages of development. ${ }^{9}$ The next structural current-account determinant is the expected growth rate of GDP over the following five years (Expected growth). This variable is likely to have a negative effect on the current account, since expected future income increases result in higher consumption and lower savings. ${ }^{10}$ We also include the lagged value of net foreign assets relative to GDP (NFA) and expect it to positively influence a country's current account, since a higher level of net foreign assets usually raises primary income. In addition, we include a dummy for any country-period characterized by a ratio of NFA to GDP below minus 60 percent (NFA (highdebt)) and thus allow for a nonlinear effect of the NFA position on the current account. The next structural current-account determinant we use is the availability of exhaustible natural resources - specifically oil and natural gas (Oil/gas trade balance): countries with large oil and gas reserves are expected to have higher current accounts ceteris

\footnotetext{
${ }^{7}$ See Tables 5 and 6 in the Appendix for a more detailed description of the variables and their respective sources.

${ }^{8}$ An extensive description of the original methodology as well as the data of the IMF is provided by Phillips et al. (2013). Note that there have been several updates of the method and specification since the introduction of the EBA analysis. The 2015 update, which changed the demographic variables in the regression, is reflected in our methodology, while the most recent update from June 2018 is not taken into account (IMF (2017)). The last update does not directly affect any of the new variables that we introduce, though.

${ }^{9}$ This is pointed out by Reinhardt et al. (2013). Note that we also include the degree of capital openness itself. However, since this variable is directly influenced by policy makers, we assign it to the group of policy variables.

${ }^{10}$ Note that the theoretical argument we developed in the preceding subsection linked the current account to expected future growth associated with the expansion of a productivity-enhancing services sector. We use the variable Expected growth predominantly to be in line with the IMF's approach, but also to account for all the other sources of growth and growth expectations.
} 
paribus, since residents save for the time after the depletion of these reserves. The variable used in the EBA regression not only reflects current exports of these resources, but also their estimated stock.

Demographic variables are also potentially important structural determinants of savings, investment, and the current account. They enter the EBA regression in various ways: while countries' old age dependency ratios (Old age dependency ratio) and population growth rates (Population growth) have always been accounted for - and are expected to affect the current account in a negative way - the IMF has recently started to include interaction terms of the relative aging speed of an economy with the old age dependency ratio (Rel. aging speed \# old age dependency ratio) and of the relative old age dependency ratio interacted with the aging speed (Rel. old age dependency ratio \# aging speed). Both terms are expected to increase the current account. The EBA approach also includes a dummy variable for relatively small economies that can be considered "financial centers" (Financial center) and an indicator of the risk associated with the institutional or political environment in the country, since risk is likely to decrease investment and increase savings of agents in an economy. A higher degree of risk is thus expected to increase the current account balance. In the context of the EBA regression, this means that the coefficient is expected to be negative as the risk indicator (Safe institutions) is constructed such that a higher value is associated with a safer environment.

We also adopt the IMF's argument that countries whose currency plays an important role in the global stock of foreign reserves can afford to have lower current accounts, and therefore include the reserve currency share (Reserve currency), expecting it to have a negative effect. Finally, global capital market conditions are taken into account by including two variables based on the VIX, an index that is calculated using implied volatilities for options on the S\&P index, and that indicates the degree of global risk aversion. The first variable based on the VIX is the lagged value of the index (VIX) interacted with the degree of capital openness (VIX \# capital openness). The coefficient of this interaction term is expected to be positive i.e. a higher degree of global risk aversion is likely to increase a country's current account, provided that the country is sufficiently exposed to global capital markets. Furthermore, the interaction of the VIX with capital openness is then also interacted with the share of a country's currency in world reserves (VIX \# capital openness \# Reserve currency): for countries whose currency has the status of a world reserve currency, the VIX is expected to raise capital inflows, implying that the coefficient for this variable should be negative.

The third group of regressors included in the EBA regression covers a set of policy variables, that is, current account determinants that are especially affected by the decisions of policy makers. The fiscal balance (Fiscal balance) is included to account for any effects of the fiscal policy stance on national savings, investment, and the current account. ${ }^{11}$ Note that the EBA approach implicitly uses the cyclically-adjusted fiscal balance, since cyclical effects are already controlled for by including the output gap in the regression. This allows estimating the direct effect of the policy choice while controlling for cyclical effects on the fiscal balance. Since the strong version of Ricardian equivalence is unlikely to hold in reality, we expect a higher fiscal balance to increase the current account. The second policy variable is the ratio of public spending on health over GDP (Health spending). Government spending on health should reduce the risk for consumers and, therefore lower the need for savings. As a consequence, we expect a negative effect of

\footnotetext{
${ }^{11}$ Note that the IMF includes the cyclically adjusted fiscal balance in order to distinguish policy choices from the effects of booms and recessions. The specific approach to performing this adjustment differs across countries (see the data descriptions in the Appendix), i.e. the cyclically adjusted fiscal balance does not always reflect the residuals from a regression of the original fiscal balance on the output gap. As described in Phillips et al. (2013) the variable is instrumented. See Table 5 for a list of the instruments. The EBA data set offers predicted values from the first-stage regression. See (Phillips et al., 2013, footnote 18.).
} 
health spending on the current account. Furthermore, Phillips et al. (2013) add the instrumented ratio of the change in foreign-exchange reserves to GDP (FX intervention) interacted with an index of capital openness (FX intervention \# capital openness) to the list of potential current-account determinants. The reasoning behind this choice is that exchange rate interventions should affect the current account of an economy as long as capital flows are restricted to some degree. To account for potential endogeneity - i.e. the possibility that interventions in the forex market result from current-account movements - this variable is instrumented. We expect an increase in reserve accumulation to positively affect the current account for a country with limited capital mobility. Lastly, to account for the effect of financial policies, the ratio of private credit to GDP (Private credit) is included in the regression and expected to decrease the current account of an economy. While Phillips et al. (2013) mainly argue that the variable allows controlling for excesses in the financial sector and their negative pressure on the current account, we can also refer to the argument of Bracke et al. (2010) and Chinn and Ito (2008a) that a better developed financial sector lessens the need for savings and therefore decreases an economy's current account.

Note that, following the IMF's methodology, we define most variables relative to their global (GDPweighted) averages. ${ }^{12}$ This means that we do not include, for instance, a country's fiscal balance, but rather the fiscal balance relative to the global (GDP-weighted) average of fiscal balances in our sample. The intuition behind this approach is straightforward. If the fiscal balance were exactly the same in all countries, the effect on the current account would be zero. Only when countries deviate from the global average should we expect to see some effect on the current account.

The original EBA dataset provided by the IMF covers 49 countries with yearly data from 1986 to 2013 . This sample size is reduced in the cross-sectional dimension, since detailed data on sectoral structure are available for only 40 countries.

The coefficients of equation (20) are estimated using a pooled OLS regression with an AR(1) correction of the disturbances and country-specific heteroskedasticity. There are two reasons why we do not include country fixed effects: the first one reflects the normative ambition of the IMF's EBA approach. In addition to many country-specific non-observables, fixed effects would also capture persistent distortions that may give rise to exceptionally high or low current account balances. This would improve the explanatory power of the model and reduce omitted-variable bias, but it would also substantially lower researchers' ability to identify and interpret "current account gaps". Since we will later explore whether and how the consideration of services affects those gaps, we adopt the IMF's model specification. ${ }^{13}$ The second reason for omitting country fixed effects is more profane: since structural change takes place at a rather slow pace, it is quite likely that the elimination of the cross-sectional component leaves very little variation in variables that reflect the sectoral composition of a country's GDP.

\footnotetext{
${ }^{12}$ Tables 5 and 6 in the Appendix show which variables are defined relative to the global averages.

${ }^{13}$ It is also for this reason that neither the original EBA approach nor our extended specification includes time dummies. However, the fact that most regressors are expressed as deviations from cross-country means reduces the risk of our results being driven by aggregate developments.
} 


\subsection{Measuring Producer Services}

The contribution of our analysis is to add variables that reflect the importance of producer services to the other structural determinants of current accounts already identified by the IMF's EBA analysis, and to demonstrate that this extension improves the explanatory power of the empirical model.

We will start by showing that a higher share of producer services in GDP (Producer services share) reduces countries' current account balance. To account for the role of the other sectors, we also include the share of consumer services (Consumer services share) as well as the share of the production sector (Production share). ${ }^{14}$ In a next step, we will explore whether the specific forces described by our model i.e. an expansion of output driven by firms' choice to outsource producer services to an increasing number of specialized providers - are supported by the data. In order to measure the extent of outsourcing, we adopt the approach of Oulton (2016) and calculate the Domar sum (DomSum) for the production sector and the consumer services sector. The Domar sum goes back to Domar (1961) and is the weighted average of the degree of outsourcing across industries.

$$
\operatorname{DomSum}_{t}=\sum_{j=1}^{N_{t}} d_{j t}=\sum_{j=1}^{N_{t}}\left(u_{j t} \mu_{j t}\right)
$$

In this expression, $d_{j t}$ is the "Domar weight" of industry $j$ at time $t$ (with $j=1,2, \ldots, N_{t}$ ), $u_{j t}$ is the gross output of industry $j$ divided by the value added of the same industry, and $\mu_{j t}$ is the value added share of industry $j$ in the economy. There are some notable characteristics of the Domar-sum (Oulton (2016)): if every industry only produces and sells final goods, the Domar-sum equals unity. With the introduction of outsourcing, adding up the Domar weights over all industries results in a value strictly above one, since the value of some industries' gross output exceeds their value added. Hence, the Domar-sum increases in an economy in which intermediate inputs - including producer services - gain importance. To calculate the Domar-sum and weights of individual industries, we use the 2016 edition of the Trade in Value Added (TiVA) database developed by the OECD and the WTO. ${ }^{15}$ In the classification scheme of industries we follow Oulton (2016). We also use the TiVA database to calculate the value added shares of producer services, consumer services, and of the production sector. For the years not covered by the TiVA database, we filled the gaps by using the current version of the OECD's STAN database if possible. ${ }^{16}$

To test our model's prediction that the expansion of producer services affects the current account by enabling final-goods industries to realize productivity-enhancing outsourcing, we interact the share of producer services in GDP with the Domar sum of the production sector (Producer services share \# Production Domar) and with the Domar sum of consumer services (Producer services share \# Consumer services Do-

\footnotetext{
${ }^{14}$ The production sector includes agriculture. As in Oulton (2016) these three groups (producer services, consumer services, production) represent the market sector of an economy and do not add up to unity. Hence, all three groups can be included in a regression without running into the problem of perfect collinearity. For a detailed definition of our industry classification see Table 4 in the Appendix.

${ }^{15}$ The database is available online and can be found at http://www.oecd.org/sti/ind/ measuring-trade-in-value-added.htm Last accessed on 19th August 2018.

${ }^{16}$ See http: //www. oecd.org/sti/ind/stanstructuralanalysisdatabase.htm. Last accessed on 19th August 2018.
} 
mar). Given the logic of our theoretical model, we expect a negative coefficient for these terms, i.e. the negative marginal effect of producer services further decreases in the Domar sum of industries that produce final goods and (consumer) services.

\subsection{Estimation Results}

Table 2 displays the results of estimating equation (20). The first column is based on a replication of the EBA specification described in Phillips et al. (2013). We show the results of estimating this specification in order to assess whether and how including the new variables change the results with respect to the estimated effects of the current account determinants in the standard EBA specification. The numbers presented in this column demonstrate that, by and large, we are able to replicate the IMF's findings. ${ }^{17}$

The coefficients displayed in column (2) of Table 2 show the results of estimating the standard EBA specification once more, but limiting the sample to the time periods for which we have data on the industrial structure and the Domar sum. We show these results to demonstrate that the improvements that we will see in our extended specifications is not only due to an adjustment of the sample. The estimation in column (2) will serve as our benchmark specification and help us to assess how the goodness of fit of our model is improved by controlling for countries' sectoral structure and the extent of outsourcing.

Column (3) adds the sectoral shares Producer services share, Consumer services share, and Production share. Despite the substantial sample reduction compared to column (1), the qualitative results of the IMF's EBA analysis are essentially preserved. ${ }^{18}$ This supports the idea that our extended EBA specification does not so much change any previously measured effect, but rather help explain previously unexplained parts of the variation in the current account. Concerning our main variables of interest - the sectoral shares we see a negative and significant coefficient for the share of producer services in column (3). While the coefficient for consumer services is also significant and negative it is less than half of the producer services coefficient (in absolute terms), supporting the hypothesis of producer services playing a special role for the current account. Note, moreover, that the inclusion of sectoral shares increases the model's explanatory power, raising the adjusted $R^{2}$ by 4.9 percentage points (from 0.601 to 0.650 ) compared to the original EBA specification using the restricted sample. In addition, we see the root mean squared error (RMSE) dropping from 0.030 in the baseline specification to 0.028 . This supports the idea that the inclusion of the new variables contributes to explaining the remaining residuals of the original EBA regression approach.

Column (4) shows the results of augmenting the previous specification by interaction terms that multiply producer services with the Domar sums of the consumer services and the production sectors, respectively. ${ }^{19}$ In addition, the combined Domar sum of the consumer services sector and the production sector (Final goods Domar) is included as a regressor. The numbers in the fourth column show that the coefficients of the interaction terms are negative and highly significant, suggesting that the marginal effect of producer

\footnotetext{
${ }^{17}$ To make the baseline result comparable to subsequent specifications, we limit the sample to the 40 countries for which we have data on the sectoral structure. This explains the differences to the official EBA-results.

${ }^{18}$ While we see some changes in the coefficients, and some coefficients that even change their significance level or become insignificant, the signs of the coefficients generally do not change after including the additional variables.

${ }^{19}$ For the specification displayed in column (4) we also see that the signs of the coefficients of column (1) are mostly preserved. The sole exception is the coefficient of the interaction term of output per worker and capital openness which drops from being significantly positive to insignificantly negative.
} 
Table 2: EBA-Regressions

\begin{tabular}{|c|c|c|c|c|c|}
\hline \multirow{2}{*}{ VARIABLES } & (1) & (2) & (3) & (4) & (5) \\
\hline & \multicolumn{5}{|c|}{ Current account ( $\%$ of GDP) } \\
\hline \multicolumn{6}{|l|}{ Cyclical variables } \\
\hline Output gap & $\begin{array}{c}-0.414 * * * \\
(0.000)\end{array}$ & $\begin{array}{c}-0.474 * * * \\
(0.000)\end{array}$ & $\begin{array}{c}-0.466^{* * * *} \\
(0.000)\end{array}$ & $\begin{array}{c}-0.454 * * * \\
(0.000)\end{array}$ & $\begin{array}{c}-0.453 * * * \\
(0.000)\end{array}$ \\
\hline Commodity ToT & $\begin{array}{c}0.138^{* * *} * \\
(0.007)\end{array}$ & $\begin{array}{l}0.097^{*} \\
(0.074)\end{array}$ & $\begin{array}{c}0.080 \\
(0.113)\end{array}$ & $\begin{array}{c}0.069 \\
(0.166)\end{array}$ & $\begin{array}{l}0.083^{*} \\
(0.095)\end{array}$ \\
\hline \multicolumn{6}{|l|}{ Policy variables } \\
\hline Output per worker \# capital openness & $\begin{array}{c}0.069 * * \\
(0.011)\end{array}$ & $\begin{array}{c}0.086 * * \\
(0.017)\end{array}$ & $\begin{array}{c}0.029 \\
(0.418)\end{array}$ & $\begin{array}{l}-0.002 \\
(0.950)\end{array}$ & $\begin{array}{c}0.005 \\
(0.891)\end{array}$ \\
\hline VIX \# capital openness & $\begin{array}{c}0.047 * * * \\
(0.004)\end{array}$ & $\begin{array}{c}0.056^{* * * *} \\
(0.003)\end{array}$ & $\begin{array}{c}0.061 * * * \\
(0.001)\end{array}$ & $\begin{array}{c}0.062 * * * \\
(0.001)\end{array}$ & $\begin{array}{c}0.067 * * * \\
(0.000)\end{array}$ \\
\hline VIX \# capital openness \# Reserve currency & $\begin{array}{l}-0.100 \\
(0.136)\end{array}$ & $\begin{array}{l}-0.121 \\
(0.139)\end{array}$ & $\begin{array}{l}-0.110 \\
(0.156)\end{array}$ & $\begin{array}{l}-0.113 \\
(0.160)\end{array}$ & $\begin{array}{l}-0.124 \\
(0.120)\end{array}$ \\
\hline Fiscal balance & $\begin{array}{c}0.361 * * * \\
(0.000)\end{array}$ & $\begin{array}{c}0.532 * * * \\
(0.000)\end{array}$ & $\begin{array}{c}0.344 * * * \\
(0.005)\end{array}$ & $\begin{array}{c}0.315 * * * \\
(0.009)\end{array}$ & $\begin{array}{c}0.303^{* *} \\
(0.013)\end{array}$ \\
\hline Health spending & $\begin{array}{c}-0.517 * * * \\
(0.001)\end{array}$ & $\begin{array}{c}-0.435^{* *} \\
(0.021)\end{array}$ & $\begin{array}{l}-0.204 \\
(0.251)\end{array}$ & $\begin{array}{l}-0.173 \\
(0.330)\end{array}$ & $\begin{array}{l}-0.155 \\
(0.390)\end{array}$ \\
\hline FX intervention \# capital openness & $\begin{array}{c}0.162 \\
(0.403)\end{array}$ & $\begin{array}{c}0.363 \\
(0.116)\end{array}$ & $\begin{array}{c}0.204 \\
(0.359)\end{array}$ & $\begin{array}{c}0.095 \\
(0.676)\end{array}$ & $\begin{array}{c}0.022 \\
(0.922)\end{array}$ \\
\hline Private credit & $\begin{array}{c}-0.023 * * * \\
(0.006)\end{array}$ & $\begin{array}{c}-0.026^{* * *} \\
(0.006)\end{array}$ & $\begin{array}{c}-0.020 * * \\
(0.029)\end{array}$ & $\begin{array}{c}-0.021 * * \\
(0.022)\end{array}$ & $\begin{array}{c}-0.020^{* *} \\
(0.038)\end{array}$ \\
\hline \multicolumn{6}{|l|}{ Structural variables } \\
\hline Output per worker & $\begin{array}{c}0.017 \\
(0.533)\end{array}$ & $\begin{array}{c}0.030 \\
(0.424)\end{array}$ & $\begin{array}{c}0.097 * * * \\
(0.006)\end{array}$ & $\begin{array}{c}0.120 * * * \\
(0.001)\end{array}$ & $\begin{array}{c}0.107 * * * \\
(0.003)\end{array}$ \\
\hline Expected growth & $\begin{array}{c}-0.474 * * * \\
(0.001)\end{array}$ & $\begin{array}{c}-0.457 * * * \\
(0.008)\end{array}$ & $\begin{array}{c}-0.609 * * * \\
(0.000)\end{array}$ & $\begin{array}{c}-0.667 * * * \\
(0.000)\end{array}$ & $\begin{array}{c}-0.676 * * * \\
(0.000)\end{array}$ \\
\hline NFA & $\begin{array}{c}0.017 * * \\
(0.011)\end{array}$ & $\begin{array}{c}0.016^{* *} \\
(0.040)\end{array}$ & $\begin{array}{c}0.022 * * * \\
(0.003)\end{array}$ & $\begin{array}{c}0.018^{* *} \\
(0.016)\end{array}$ & $\begin{array}{c}0.016^{* * *} \\
(0.040)\end{array}$ \\
\hline NFA (highdebt) & $\begin{array}{l}-0.012 \\
(0.427)\end{array}$ & $\begin{array}{l}-0.004 \\
(0.831)\end{array}$ & $\begin{array}{l}-0.016 \\
(0.324)\end{array}$ & $\begin{array}{l}-0.014 \\
(0.386)\end{array}$ & $\begin{array}{l}-0.009 \\
(0.561)\end{array}$ \\
\hline Oil/gas trade balance & $\begin{array}{c}0.395 \\
(0.103)\end{array}$ & $\begin{array}{c}0.603 * * \\
(0.036)\end{array}$ & $\begin{array}{c}0.188 \\
(0.463)\end{array}$ & $\begin{array}{c}0.292 \\
(0.261)\end{array}$ & $\begin{array}{c}0.346 \\
(0.198)\end{array}$ \\
\hline Old age dependency ratio & $\begin{array}{l}-0.038 \\
(0.540)\end{array}$ & $\begin{array}{c}-0.149 * \\
(0.086)\end{array}$ & $\begin{array}{c}-0.147^{*} \\
(0.069)\end{array}$ & $\begin{array}{c}-0.237 * * \\
(0.011)\end{array}$ & $\begin{array}{c}-0.195 * * \\
(0.039)\end{array}$ \\
\hline Population growth & $\begin{array}{l}-0.147 \\
(0.728)\end{array}$ & $\begin{array}{l}-0.207 \\
(0.661)\end{array}$ & $\begin{array}{l}-0.016 \\
(0.972)\end{array}$ & $\begin{array}{l}-0.421 \\
(0.357)\end{array}$ & $\begin{array}{l}-0.305 \\
(0.516)\end{array}$ \\
\hline Rel. old age dependency ratio \# aging speed & $\begin{array}{c}0.147 * * * \\
(0.000)\end{array}$ & $\begin{array}{c}0.094 * * \\
(0.047)\end{array}$ & $\begin{array}{c}0.056 \\
(0.198)\end{array}$ & $\begin{array}{c}0.032 \\
(0.482)\end{array}$ & $\begin{array}{c}0.042 \\
(0.366)\end{array}$ \\
\hline Rel. aging speed \# old age dependency ratio & $\begin{array}{c}0.044 \\
(0.383)\end{array}$ & $\begin{array}{l}0.139 * \\
(0.100)\end{array}$ & $\begin{array}{c}0.116 \\
(0.134)\end{array}$ & $\begin{array}{c}0.217 * * \\
(0.012)\end{array}$ & $\begin{array}{c}0.205^{* *} \\
(0.020)\end{array}$ \\
\hline Financial center & $\begin{array}{c}0.023 * * * \\
(0.005)\end{array}$ & $\begin{array}{c}0.021 * * \\
(0.017)\end{array}$ & $\begin{array}{c}0.031 * * * \\
(0.000)\end{array}$ & $\begin{array}{c}0.037 * * * \\
(0.000)\end{array}$ & $\begin{array}{c}0.036^{* * *} \\
(0.000)\end{array}$ \\
\hline Safe institutions & $\begin{array}{c}-0.112 * * * \\
(0.000)\end{array}$ & $\begin{array}{c}-0.140 * * * \\
(0.000)\end{array}$ & $\begin{array}{c}-0.119 * * * \\
(0.000)\end{array}$ & $\begin{array}{c}-0.110^{* * *} \\
(0.000)\end{array}$ & $\begin{array}{c}-0.108 * * * \\
(0.000)\end{array}$ \\
\hline Reserve currency & $\begin{array}{c}-0.052 * * * \\
(0.000)\end{array}$ & $\begin{array}{c}-0.070 * * * \\
(0.000)\end{array}$ & $\begin{array}{c}-0.059 * * * \\
(0.000)\end{array}$ & $\begin{array}{c}-0.067 * * * \\
(0.000)\end{array}$ & $\begin{array}{c}-0.068 * * * \\
(0.000)\end{array}$ \\
\hline \multicolumn{6}{|l|}{ Sectoral structure variables } \\
\hline Producer services share & & & $\begin{array}{c}-0.057 * * * \\
(0.003)\end{array}$ & $\begin{array}{c}-0.037 * * \\
(0.047)\end{array}$ & $\begin{array}{l}-0.026 \\
(0.197)\end{array}$ \\
\hline Consumer services share & & & $\begin{array}{c}-0.025^{* *} \\
(0.050)\end{array}$ & $\begin{array}{c}-0.038^{* * *} * \\
(0.009)\end{array}$ & $\begin{array}{l}-0.008 \\
(0.692)\end{array}$ \\
\hline Production share & & & $\begin{array}{c}0.059 * * * \\
(0.000)\end{array}$ & $\begin{array}{c}0.061 * * * \\
(0.002)\end{array}$ & $\begin{array}{c}0.049 * * \\
(0.026)\end{array}$ \\
\hline Producer services share \# Production Domar & & & & $\begin{array}{c}-0.131 \text { *** } \\
(0.002)\end{array}$ & $\begin{array}{c}-0.115 * * * \\
(0.007)\end{array}$ \\
\hline Producer services share \# Consumer services Domar & & & & $\begin{array}{c}-0.239^{* * *} \\
(0.001)\end{array}$ & $\begin{array}{c}-0.247 * * * \\
(0.001)\end{array}$ \\
\hline Production Domar & & & & & $\begin{array}{c}0.007 \\
(0.646)\end{array}$ \\
\hline Consumer service Domar & & & & & $\begin{array}{c}-0.051 * * * \\
(0.004)\end{array}$ \\
\hline Final goods Domar & & & & $\begin{array}{c}-0.012 \\
(0.214)\end{array}$ & \\
\hline Constant & $\begin{array}{c}-0.014 * * * \\
(0.000)\end{array}$ & $\begin{array}{c}-0.018^{* * *} \\
(0.000)\end{array}$ & $\begin{array}{c}-0.021^{* * *} * \\
(0.000)\end{array}$ & $\begin{array}{c}-0.024^{* * *} * \\
(0.000)\end{array}$ & $\begin{array}{c}-0.021 * * * \\
(0.000)\end{array}$ \\
\hline Observations & 1,001 & 674 & 674 & 674 & 674 \\
\hline R-squared & 0.517 & 0.613 & 0.662 & 0.686 & 0.692 \\
\hline Adj. R-squared & 0.507 & 0.601 & 0.650 & 0.673 & 0.679 \\
\hline Number of IMFCodes & 40 & 40 & 40 & 40 & 40 \\
\hline Root MSE & 0.031 & 0.030 & 0.028 & 0.027 & 0.027 \\
\hline
\end{tabular}

$\mathrm{P}$-values of heteroscedasticity-corrected z-statistics in parentheses

$* * * \mathrm{p}<0.01, * * \mathrm{p}<0.05, * \mathrm{p}<0.1$ 
services on the current account decreases in the "final goods" industries' Domar shares. This provides support to the idea that the effect of producer services on the current account balance runs through the outsourcing mechanism proposed by our theoretical model.

Column (5) also uses the combination of sectoral shares and interaction terms, but includes the Domar sums of the production sector and of the consumer services sector (Production Domar and Consumer services Domar) as separate regressors. While the negative sign of producer services is preserved, the coefficient is no longer significantly different from zero. By contrast, the interaction terms of producer services with the Domar sum in the production sector and in the consumer services sector are still negative and highly significant. Concerning the goodness of fit, we see that the adjusted $R^{2}$ further increases to a value of 0.679 in our most extensive specification in column (5).

So far, we have found that our proxies for countries' sectoral structure and the extent of outsourcing have a significant effect on the current account in the same period. However, taken literally, our model suggests that it is the future increase of outsourcing (and the resulting gains from specialization) that reduces a country's current account balance. ${ }^{20}$ To test this relationship more directly, we re-ran all regressions from Table 2, using the first lead of sectoral shares and of the interaction terms with the extent of outsourcing. The results of this modified specification are presented in Table 7 in the Appendix. They indicate that our previous findings prevail if we use future (instead of contemporaneous) values of an economy's sectoral structure.

\subsection{Producer Services and Current Account Gaps}

Using the estimation results presented in the previous section, we can explore whether and how the explicit consideration of services affects the normative part of the EBA analysis. More specifically, we look at the change of countries' "current account gaps", i.e. the difference between observed cyclically adjusted current-account balances and those levels of the current account that can be explained on the basis of fundamental parameters and desired levels of policy variables. Adopting the IMF's terminology, the total gap is the difference between countries' observed cyclically adjusted current accounts (relative to their GDP) and their current account norms. These current account norms, in turn, are computed by combining the estimated coefficients with the observed values of structural variables, and the "desirable" levels of the policy variables as defined by the IMF. ${ }^{21}$ The current account gap thus represents the sum of the regression residual and the policy gap, with the latter resulting from the difference between observed and desirable levels of the policy variables.

We perform this analysis by comparing the resulting EBA norms of the standard specification with those of our extended estimations for two countries that have exhibited persistent current account deficits over the past years - the United Kingdom and the United States - and two countries with persistent surpluses - Japan

\footnotetext{
${ }^{20}$ Of course, our model suggests that future GDP positively depends on the current size of the producer services sector through the effect of $X_{t}$ on $x_{i, t+1}$, as specified by (11).

${ }^{21}$ Note that we neither question nor modify the desirable levels of policy variables, as published by the IMF. Moreover, we follow the IMF in basing predicted values on structural-variable coefficients that have the sign predicted by theory, regardless of their statistical significance. By contrast, policy variables are only included in the prediction if their coefficients are significantly different from zero. Finally, we treat the variables on sectoral composition and outsourcing as structural instead of policy variables although fixed costs of operating producer services firms may be affected by policy choices. However, we do not know the "desirable" level of regulation that we would have to impose.
} 
Figure 4: EBA Norms

Deficit Economies: United States (left) and the United Kingdom (right)
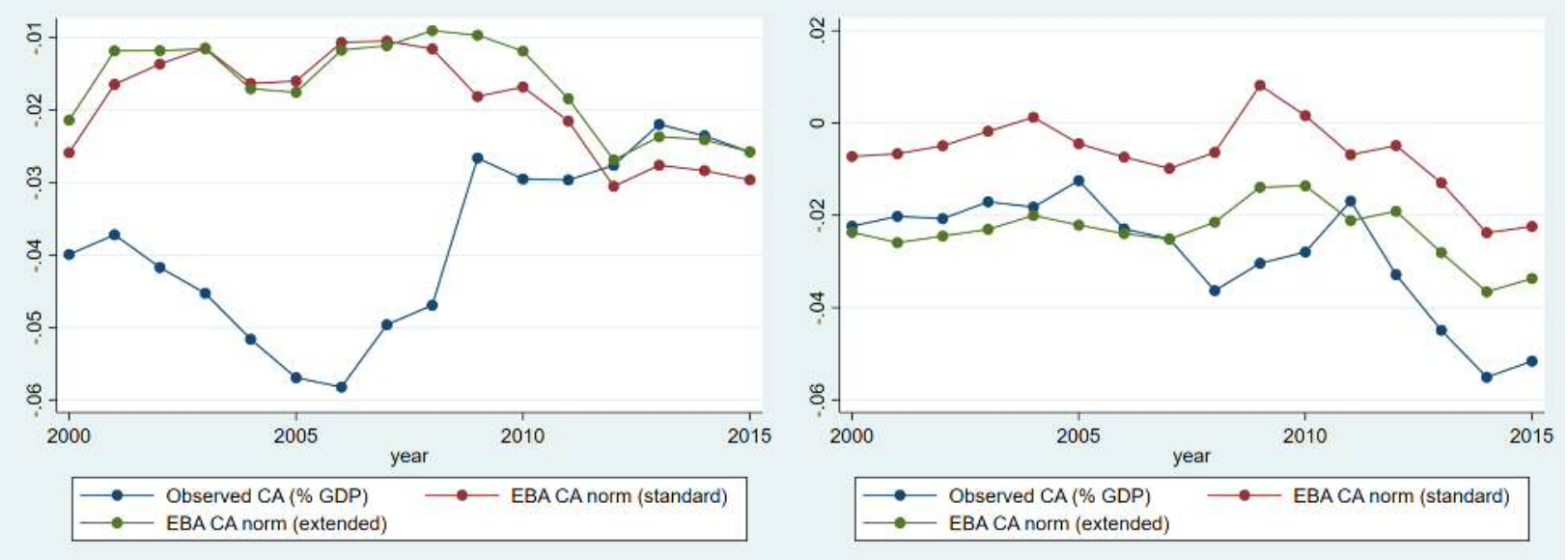

Surplus Economies: Japan (left) and Germany (right)
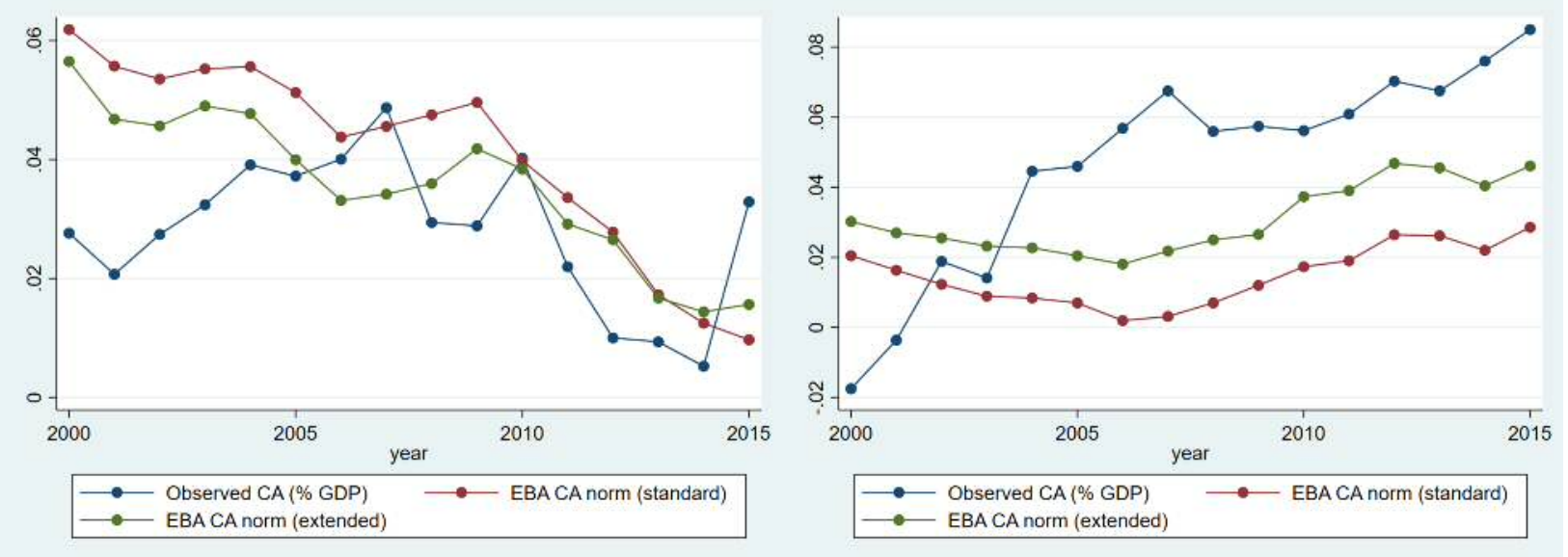

and Germany. ${ }^{22}$ If the inclusion of the sectoral structure and importance of outsourcing is empirically and economically relevant, we should see the extended approach reducing the total gap of the EBA approach over the studied time horizon. We calculate the EBA norms, policy gaps, residual and cyclical component for the years 2000 to 2015 and compare the most extensive specification (see column (5)) in Table 2 with the baseline EBA result in column (2). ${ }^{23}$ The blue lines in Figure 4 show the observed current account balances (relative to GDP), the red lines show the EBA current account norms of the standard specification, and the green lines show the current account norms resulting from our extended approach. The gap between the depicted current account balance and the respective EBA norm is the sum of the cyclical component of the current account and the remaining total gap, which reflects both the deviation from desirable policies - i.e. the policy gap - and the regression residual. We can observe that, for all four countries, the consideration of countries' sectoral structure and the extent of outsourcing lowers the total gap for the year 2015. Table 3 shows the average current account norms and gaps for the four countries mentioned above, and the average of the whole sample for years from 2000 to 2015. For the United States the absolute total gap relative to GDP decreases from $0.27 \%$ to $0.11 \%$, for the United Kingdom from $2.59 \%$ to $1.47 \%$, for Japan from $1.86 \%$

\footnotetext{
${ }^{22}$ An overview over the results for the full sample of countries can be found in Table 8 in the Appendix.

${ }^{23}$ For those countries in our sample for which no data is available for the years after 2013, we calculate the EBA norms up to 2013.
} 
to $1.30 \%$, and for Germany from $5.93 \%$ to $4.18 \%$.

While the difference between the benchmark and the extended specification is rather small for the US ( $0.16 \%$ for 2015$)$, it is quite substantial for the other three countries, ranging from $0.56 \%$ to $1.75 \%$. For these countries, we also see a lower average total gap when we consider the entire time horizon from 2000 to 2015. By contrast, the average gap for the entire time span is slightly higher for the US, using the new specification, although, as Figure 4 shows, the calculated EBA norms based on the extended specification have been quite close to the observed current account values since 2012. These observations generally support our hypothesis that accounting for countries' sectoral structure and the role of producer services moves the estimated current account norms closer to the actual cyclically adjusted balances.

Since the calculated total gaps consist of two parts - the policy gap and the unexplained residual - it is of interest where the change in the calculated gaps is originating from. On the one hand, a change in the policy gap could indicate that the effect of policy variables on the current account varies due to the extended specification. On the other hand, a decrease in the residual would show that some part of the variation of the current account that was previously unexplained can now be attributed to a change in a structural variable. As is shown in Table 3, the average residual decreases as a result of using the extended specification for three out of the four countries considered. ${ }^{24}$ In the case of Germany, this increase is quite substantial, with a reduction of the average absolute residual by $1.35 \%$. For Japan and the UK we see a more modest reduction by $0.23 \%$ and $0.16 \%$, respectively.

Looking at the entire sample of countries, we find that adding our sectoral variables to the standard EBA specification lowers the average current account gap from $3.13 \%$ to $2.49 \%$ of GDP, and the average residual from $2.50 \%$ to $2.21 \%$ of GDP (see the last column in Table 3 ).

Table 3: EBA Current Account Gaps and Residuals (in percent)

\begin{tabular}{lccccc}
\hline & United States & United Kingdom & Japan & Germany & Sample \\
Standard Specification & & & & & \\
Average Gap (2000-2015) & 2.06 & 2.11 & 2.08 & 4.01 & 3.13 \\
Average Policy Gap (2000-2015) & 1.11 & 1.98 & 2.02 & 1.27 & 2.05 \\
Average Residual (2000-2015) & 1.63 & 1.17 & 1.17 & 3.83 & 2.50 \\
Average Cyclical Component (2000-2015) & 0.52 & 0.30 & 0.58 & 0.59 & 0.79 \\
& & & & & \\
Extended Specification & & & & & \\
Average Gap (2000-2015) & 2.23 & 1.10 & 1.54 & 2.87 & 2.49 \\
Average Policy Gap (2000-2015) & 0.55 & 1.14 & 1.13 & 0.73 & 1.05 \\
Average Residual (2000-2015) & 1.86 & 1.01 & 0.94 & 2.48 & 2.21 \\
Average Cyclical Component (2000-2015) & 0.50 & 0.29 & 0.55 & 0.56 & 0.75 \\
\hline
\end{tabular}

Gaps, Residuals and Cyclical Components are calculated in absolute terms. All values are relative to GDP.

All in all, we can thus observe that the new specification helps to reduce current account gaps, although the impact varies across countries. On average, we find that the regression residual decreases for the entire sample. At the same time we also find a decrease in the average absolute policy gaps by $1.00 \%$ of GDP as a result of introducing our new variables. This implies that although some part of the current account

\footnotetext{
${ }^{24}$ For the United States, the average absolute residual increases by $0.23 \%$ which is very close to the actual increase of the average gap for the time horizon.
} 
variation that was previously unexplained can now be attributed to the outsourcing effect, there is also some change in the evaluation of policy variables and of their effect on the current account.

\section{Conclusion}

The aim of this paper was to present an explanation for the observed negative relationship between the service share in countries' GDP and their current-account balances. Our hypothesis was that a larger services sector also reflects the importance of producer services, and that the latter increase an economy's aggregate productivity due to increasing returns to specialization. Our theoretical model described this mechanism in detail and demonstrated how, by facilitating the expansion of producer services in the future, a larger services sector reduces aggregate saving and the current account.

Taking the model's results to the data, we tested whether explicitly considering countries' sectoral structure and the extent of outsourcing contributes to explaining countries' current accounts in the context of the IMF's External Balance Assessment (EBA). We showed that taking these new variables into account improves the fit of EBA regressions, and that the signs of the estimated coefficients support the model's hypothesis.

In a last step, we used the extended specification to compute EBA current account norms and demonstrated that, on average, the explicit consideration of producer services and outsourcing lowers total current account gaps for most economies in our sample.

We see our analysis as contributing to a better understanding of the role of structural change in general - and of services in particular - for countries' current accounts. More specifically, we believe that our focus on the productivity-enhancing effect of producer services offers an alternative to the "Dutch disease"-type explanations of the relationship between the size of the services sector and external imbalances. While our model was built on the assumption that services are non-tradable, a natural extension of our analysis would account for the increasing tradability of services. We thus believe that our approach offers ample scope for future research.

\section{References}

Amdur, D. and Kiziler, E. E. (2014). Trend shocks and the countercyclical U.S. current account. Canadian Journal of Economics/Revue canadienne d'économique, 47(2):494-516.

Barattieri, A. (2014). Comparative Advantage, Service Trade, and Global Imbalances. Journal of International Economics, 92(1):1-13.

Baumol, W. J. (1967). Macroeconomics of Unbalanced Growth: The Anatomy of Urban Crisis. The American Economic Review, 57(3):415-426.

Bems, R., Dedola, L., and Smets, F. (2007). US imbalances: The role of technology and policy. Journal of International Money and Finance, 26(4):523-545. 
Benigno, G., Converse, N., and Fornaro, L. (2015). Large capital inflows, sectoral allocation, and economic performance. Journal of International Money and Finance, 55:60-87.

Benigno, G. and Fornaro, L. (2014). The Financial Resource Curse. The Scandinavian Journal of Economics, 116(1):58-86.

Bernanke, B. et al. (2007). Global imbalances: recent developments and prospects. Bundesbank Lecture speech, September, 4:18.

Bernanke, B. S. et al. (2005). The global saving glut and the US current account deficit. Technical report. https: / / www. federalreserve.gov/boarddocs/speeches/2005/200503102/ default.htm; last accessed at 5th January 2018.

Bracke, T., Bussière, M., Fidora, M., and Straub, R. (2010). A framework for assessing global imbalances. The World Economy, 33(9):1140-1174.

Chinn, M. D. and Ito, H. (2008a). Global Current Account Imbalances: American Fiscal Policy versus East Asian Savings*. Review of International Economics, 16(3):479-498.

Chinn, M. D. and Ito, H. (2008b). A new measure of financial openness. Journal of Comparative Policy Analysis, 10(3):309-322.

Chinn, M. D. and Prasad, E. S. (2003). Medium-term determinants of current accounts in industrial and developing countries: an empirical exploration. Journal of International Economics, 59(1):47-76.

Corden, W. M. and Neary, J. P. (1982). Booming sector and de-industrialisation in a small open economy. The Economic Journal, 92(368):825-848.

De Santis, R. A. and Lührmann, M. (2009). On the determinants of net international portfolio flows: A global perspective. Journal of International Money and Finance, 28(5):880-901.

Domar, E. D. (1961). On the Measurement of Technological Change. The Economic Journal, 71(284):709729.

Ethier, W. J. (1982). National and International Returns to Scale in the Modern Theory of International Trade. The American Economic Review, 72(3):389-405.

Francois, J. and Hoekman, B. (2010). Services Trade and Policy. Journal of Economic Literature, pages 642-692.

Hoffmann, M., Krause, M. U., and Laubach, T. (2017). The Expectations-Driven US Current Account. The Economic Journal, 129(618):897-924.

Hunt, B. and Rebucci, A. (2005). The US dollar and the Trade Deficit: What Accounts for the Late 1990s? International Finance, 8(3):399-434.

IMF (2017). 2015 Refinements to the External Balance Assessment (EBA) Methodology. Technical report, International Monetary Fund.

IMF (2018). World Economic Outlook, April 2018: Cyclical Upswing, Structural Change. International Monetary Fund. 
Jin, K. (2012). Industrial Structure and Capital Flows. The American Economic Review, 102(5):2111-2146.

Lane, P. R. and Milesi-Ferretti, G. M. (2007). The external wealth of nations mark II: Revised and extended estimates of foreign assets and liabilities, 1970-2004. Journal of International Economics, 73(2):223250.

Obstfeld, M. and Rogoff, K. (1995). The Intertemporal Approach to the Current Account. Handbook of International Economics, 3:1731-1799.

Oulton, N. (2016). The Mystery of TFP. International Productivity Monitor, (31):68.

Phillips, S., Catão, L., Ricci, L., Bems, R., Das, M., Di Giovanni, J., Unsal, F., Castillo, M., Lee, J., Rodriguez, J., et al. (2013). The External Balance Assessment (EBA) Methodology. IMF Working Paper: The External Balance Assessment (EBA) Methodology, 13(272).

Quinn, D., Schindler, M., and Toyoda, A. M. (2011). Assessing Measures of Financial Openness and Integration. IMF Economic Review, 59(3):488-522.

Reinhardt, D., Ricci, L. A., and Tressel, T. (2013). International capital flows and development: Financial openness matters. Journal of International Economics, 91(2):235-251.

Romer, P. M. (1987). Growth Based on Increasing Returns Due to Specialization. The American Economic Review, 77(2):56-62.

Romer, P. M. (1990). Endogenous Technological Change. Journal of Political Economy, 98(5, Part 2):S71S102.

Timmer, M. P., Inklaar, R., O’Mahony, M., and Van Ark, B. (2011). Productivity and Economic Growth in Europe: A Comparative Industry Perspective. International Productivity Monitor, (21):3.

Weber, E., Elstner, S., Schmidt, C. M., Fritsche, U., Harms, P. C., Saam, M., Hartwig, J., and Krämer, H. (2017). Schwaches Produktivitätswachstum — zyklisches oder strukturelles Phänomen? Wirtschaftsdienst, 97(2):83-102.

\section{Appendix}

\subsection{Proofs}

Proof of Proposition 1. To prove the existence of an interior equilibrium with $0<L_{t}^{Y}<L$, we start by analyzing equation (16). Taking into account that the value of $X_{t}$ negatively depends on $L_{t}^{Y}$, i.e. labor that is employed in the final goods sector cannot be employed in the service sector, it is straightforward to show that the two values $L_{t}^{Y}=0$ and $L_{t}^{Y}=L$ solve this equation. We know that the expression on the RHS of equation (16) is continuous and differentiable in $L_{t}^{Y}$ over the interval $(0, L)$. Furthermore, we know that the expression on the left hand side of equation (16) is increasing in $L_{t}^{Y}$ at the rate $\frac{1}{L}$. The derivative of the 
expression on the right hand side of (16) with respect to $L_{t}^{Y}$ is given by

$$
\frac{\gamma}{\theta}\left(\frac{\theta+\frac{L_{t}^{Y}}{L-L_{t}^{Y}}}{L_{t}^{Y}}\right)\left(\frac{\alpha}{\alpha+(1-\alpha)\left(\frac{X_{t}}{L_{t}^{Y}}\right)^{\gamma}}\right)\left(\frac{(1-\alpha)\left(\frac{X_{t}}{L_{t}^{Y}}\right)^{\gamma}}{\alpha+(1-\alpha)\left(\frac{X_{t}}{L_{t}^{Y}}\right)^{\gamma}}\right)
$$

Taking the limit with $L_{t}^{Y} \rightarrow 0$ this expression can be shown to go to $+\infty$. For $L_{t}^{Y} \rightarrow L$ and the assumption that $\gamma<\theta$, the expression also goes to $+\infty$. We thus know that, in the immediate neighborhood of the two corner solutions of equation (16), the expression on the right hand side of (16) is increasing faster in $L_{t}^{Y}$ than the expression on the left hand side. It follows that at the borders of the open interval $(0, L)$ there must be two points $L_{t}^{Y, 1}$ and $L_{t}^{Y, 2}$, with $L_{t}^{Y, 1}<L_{t}^{Y, 2}$, and that, at $L_{t}^{Y, 1}$, the right hand side of equation (16) must exceed the left hand side. Conversely, at $L_{t}^{Y, 2}$ the left hand side exceeds the right hand side. Then, by the intermediate value theorem, there is a value $L_{t}^{Y, *} \in(0, L)$ that solves equation (16).

The next step is to show that the interior equilibrium is unique i.e. that $L_{t}^{Y \text {,* }}$ is the only solution of (16) in the interval $(0, L)$. By using equation (16), we can simplify expression (21) to get

$$
\frac{1}{L}\left(\gamma+\left(\frac{1-\theta}{\theta}\right) \gamma \frac{L_{t}^{Y, *}}{L}\right)
$$

This expression describes the reaction of the right hand side of equation (16) to an infinitesimal change in $L_{t}^{Y}$ at any solution in the interval $(0, L)$. From above, we know that the change of the left hand side in $L_{t}^{Y}$ is equal to $\frac{1}{L}$. It is easy to show that, for $\gamma<\theta$, the term in brackets of the above expression is smaller than one. Therefore, at every interior solution $L_{t}^{Y \text {,* }}$ of equation (16), the right hand side increases by less than the left hand side, which implies that there can only be one such point. Note, finally, that Assumption $1(\gamma<\theta)$ is sufficient, but not necessary for a unique interior solution to exist, i.e. an interior equilibrium may well exist in the alternative case of $\gamma \geq \theta$.

Proof of Lemma 1. To prove that a reduction of $\kappa_{t}$ will result in an increase of the equilibrium level of $s_{t}^{\text {ser }}$, it is is sufficient to show that

$$
\frac{d L_{t}^{Y, *}}{d \kappa_{t}}>0
$$

i.e. that an increase of the fixed cost component in the service sector increases equilibrium employment in the final goods sector. As there is no closed form solution for $L_{t}^{Y, *}$ the derivative of $L_{t}^{Y \text {,* }}$ with respect to $\kappa_{t}$ can only be derived by implicit differentiation of equation (16). This results in

$$
\frac{d L_{t}^{Y, *}}{d \kappa_{t}}=\frac{\left(\frac{\theta}{\gamma}-\gamma\right) \frac{L_{t}^{Y, *}}{\kappa_{t}}}{\frac{\alpha}{1-\alpha}\left(\frac{L_{t}^{Y, *}}{X_{t}}\right)^{\gamma}+(1-\gamma)-\frac{\gamma}{\theta}\left(\frac{L_{t}^{Y, *}}{L-L_{t}^{Y, *}}\right)}
$$

Using the fact, that the economy must be at the equilibrium i.e. that equation (16) must hold we can further 
simplify this to

$$
\frac{d L_{t}^{Y, *}}{d \kappa_{t}}=\frac{\left(\frac{\gamma(1-\theta)}{\theta}\right) \frac{L_{t}^{Y, *}}{\kappa_{t}}}{(1-\gamma)+\left(\frac{\theta-\gamma}{\theta}\right)\left(\frac{L_{t}^{Y, *}}{L-L_{t}^{Y, *}}\right)}
$$

which is strictly positive for $\gamma, \theta \in(0,1)$ and $\gamma<\theta$. 


\subsection{Tables}

The table lists the industries that were categorized as being part of the production sector, consumer services sector or producer services sector. All sectors not listed here are not regarded as part of the market sector. The reason for excluding the sector of Real estate activities follows Oulton (2016). An overview of the TiVA list of industries can be found at http://www.oecd.org/sti/ind/tiva/TiVA_2016_ISIC3_ Industries.pdf, last accessed on 5th October 2018.

Table 4: Sectoral Groups

\begin{tabular}{lcl}
\hline Industry Name & Code & Group \\
\hline Agriculture, hunting, forestry and fishing & C01T05 & Production \\
Mining and quarrying & C10T14 & Production \\
Manufacturing & C15T37 & Production \\
Electricity, gas and water supply & C40T41 & Production \\
Construction & C45 & Production \\
Wholesale and retail trade; repairs & C50T52 & Consumer Services \\
Hotels and restaurants & C55 & Consumer Services \\
Transport and storage, post and telecommunication & C60T64 & Producer Services \\
Financial intermediation & C65T67 & Producer Services \\
Renting and business activities* & C70T74* & Producer Services \\
\hline
\end{tabular}

*The sector of Real estate activities (C70) is excluded from the group of producer services.

The classification follows the TiVA industry list based on the ISIC Rev. 3. 
Table 5: Variable Descriptions

\begin{tabular}{|c|c|c|}
\hline Variable & Descriptions & Source \\
\hline Output gap* & IMF estimates and HP filtered estimates & IMF \\
\hline Commodity ToT & $\begin{array}{l}\text { Cyclical component of the ratio of average commodity export } \\
\text { prices to average commodity import prices (each relative to ad- } \\
\text { vanced economies' manufacturing goods prices) interacted with } \\
\text { an economy's trade openness (exports plus imports relative to } \\
\text { GDP) }\end{array}$ & IMF \\
\hline Output per worker & $\begin{array}{l}\text { Demeaned ratio of PPP-adjusted GDP to working age population } \\
\text { relative to the average of Germany, Japan and USA }\end{array}$ & IMF \\
\hline Capital openness & $\begin{array}{l}\text { Quinn index for capital controls in the private sector rescaled to } \\
\text { the interval } 0 \text { to } 1 \text {. Higher values indicate more restrictive con- } \\
\text { trols. For a description of this index and of competing measures } \\
\text { of capital controls see Quinn et al. (2011). }\end{array}$ & IMF \\
\hline VIX & $\begin{array}{l}\text { Index of implied stock market volatility offered by the Chicago } \\
\text { Board Options Exchange, interpreted as a measure of financial } \\
\text { risk aversion. }\end{array}$ & IMF \\
\hline Reserve currency & $\begin{array}{l}\text { Share of an economy's own currency in the global stock of for- } \\
\text { eign exchange reserves }\end{array}$ & IMF \\
\hline Fiscal balance* & $\begin{array}{l}\text { Instrumented cyclically-adjusted fiscal balance, based on the IMF } \\
\text { estimates or regressions of the fiscal balance on the output gap. } \\
\text { The instruments used are the lagged cyclically-adjusted global } \\
\text { fiscal balance, a time trend, lagged world GDP growth, lagged } \\
\text { domestic and world output gaps, US corporate credit spreads, the } \\
\text { foreign exchange regime, the polity index, and the cross-sectional } \\
\text { average of the fiscal balance, as well as the other regressors in- } \\
\text { cluded in the IMF's CA regression. }\end{array}$ & IMF \\
\hline Health spending* & Ratio of public health spending to GDP & IMF \\
\hline FX intervention* & $\begin{array}{l}\text { Instrumented change in central bank foreign exchange reserves, } \\
\text { scaled by GDP in current USD. Instruments used are the M2 to } \\
\text { GDP ratio, U.S. interest rates, and the global rate of reserve ac- } \\
\text { cumulation using country specific slopes, as well as the other re- } \\
\text { gressors included in the IMF's CA regression. }\end{array}$ & IMF \\
\hline Private credit* & Demeaned ratio of private credit to GDP & IMF \\
\hline Expected growth* & $\begin{array}{l}\text { Five-year forecast of real GDP growth rate, based on the IMF's } \\
\text { projections, as published in the World Economic Outlook }\end{array}$ & IMF \\
\hline NFA & $\begin{array}{l}\text { Ratio of net foreign assets to GDP based on an updated and ex- } \\
\text { tended version of the dataset by Lane and Milesi-Ferretti (2007) }\end{array}$ & IMF \\
\hline NFA (highdebt) & $\begin{array}{l}\text { Dummy variable equaling one if a country's NFA to GDP ratio is } \\
\text { below negative } 60 \%\end{array}$ & IMF \\
\hline
\end{tabular}


Table 5: Variable Descriptions (continued)

\begin{tabular}{|c|c|c|}
\hline Variable & Descriptions & Source \\
\hline Oil/gas trade balance* & $\begin{array}{l}\text { If net exports of oil and gas are greater than zero: net exports of } \\
\text { oil and gas relative to GDP, multiplied by a factor of temporari- } \\
\text { ness (rate of current extraction to proven reserves, indexed by the } \\
\text { temporariness value of Norway in 2010). Otherwise, this variable } \\
\text { is set equal to zero. Data are based on the BP Statistical Review. }\end{array}$ & IMF \\
\hline Old age dependency ratio* & Population over 65 years relative to population age 30 to 64 . & IMF \\
\hline Population growth* & Growth of population & IMF \\
\hline Aging speed* & $\begin{array}{l}\text { Projected change in the dependency ratio in } 20 \text { years relative to } \\
\text { current level }\end{array}$ & IMF \\
\hline Financial center & $\begin{array}{l}\text { Dummy variable, equaling one for The Netherlands, Switzerland } \\
\text { and Belgium (up to 2004). }\end{array}$ & IMF \\
\hline Safe institutions* & $\begin{array}{l}\text { Average of five measures from the International Country Risk } \\
\text { Guide indicating the quality of institutions and the stability of the } \\
\text { social/political environment: socioeconomic conditions, invest- } \\
\text { ment profile, corruption, religious tensions and democratic ac- } \\
\text { countability. Higher values signal a better/less risky institutional } \\
\text { environment }\end{array}$ & IMF \\
\hline
\end{tabular}

These are condensed versions of the IMF's original variable definitions, as presented in Phillips et al. (2013). Variables marked with an asterisk $\left({ }^{*}\right)$ are constructed as relative deviations from GDP-weighted (sample) averages.

Table 6: Variable Descriptions

\begin{tabular}{|c|c|c|}
\hline Variable & Descriptions & Source \\
\hline Producer services share* & Value added of the producer services sector relative to GDP. & TiVA \\
\hline Consumer services share* & Value added of the consumer services sector relative to GDP. & TiVA \\
\hline Production share* & Value added of the production sector relative to GDP. & TiVA \\
\hline Production Domar* & Domar sum of the production sector. & TiVA \\
\hline Consumer services Domar* & Domar sum of the consumer services sector. & TiVA \\
\hline Final goods Domar* & $\begin{array}{l}\text { Domar sum of the final goods sector, i.e. the production and con- } \\
\text { sumer services sector combined. }\end{array}$ & TiVA \\
\hline
\end{tabular}


Table 7: EBA-Regressions - Lead of Outsourcing Variables

\begin{tabular}{|c|c|c|c|c|c|}
\hline \multirow{2}{*}{ VARIABLES } & (1) & (3) & (2) & (4) & (5) \\
\hline & \multicolumn{5}{|c|}{ Current account ( $\%$ of GDP) } \\
\hline \multicolumn{6}{|l|}{ Cyclical variables } \\
\hline Output gap & $\begin{array}{c}-0.414 * * * \\
(0.000)\end{array}$ & $\begin{array}{c}-0.466 * * * \\
(0.000)\end{array}$ & $\begin{array}{c}-0.430^{* * * *} \\
(0.000)\end{array}$ & $\begin{array}{c}-0.429 * * * \\
(0.000)\end{array}$ & $\begin{array}{c}-0.421 * * * \\
(0.000)\end{array}$ \\
\hline Commodity ToT & $\begin{array}{c}0.138 * * * \\
(0.007)\end{array}$ & $\begin{array}{c}0.091 \\
(0.121)\end{array}$ & $\begin{array}{l}0.104 * \\
(0.078)\end{array}$ & $\begin{array}{l}0.113^{*} \\
(0.051)\end{array}$ & $\begin{array}{l}0.117 * * \\
(0.043)\end{array}$ \\
\hline \multicolumn{6}{|l|}{ Policy variables } \\
\hline Output per worker \# capital openness & $\begin{array}{c}0.069 * * \\
(0.011)\end{array}$ & $\begin{array}{c}0.086^{* *} \\
(0.014)\end{array}$ & $\begin{array}{c}0.052 \\
(0.131)\end{array}$ & $\begin{array}{c}0.023 \\
(0.512)\end{array}$ & $\begin{array}{c}0.031 \\
(0.391)\end{array}$ \\
\hline VIX \# capital openness & $\begin{array}{c}0.047 * * * \\
(0.004)\end{array}$ & $\begin{array}{c}0.062 * * * \\
(0.001)\end{array}$ & $\begin{array}{c}0.065 * * * \\
(0.001)\end{array}$ & $\begin{array}{c}0.065 * * * \\
(0.001)\end{array}$ & $\begin{array}{c}0.067 * * * \\
(0.000)\end{array}$ \\
\hline VIX \# capital openness \# Reserve currency & $\begin{array}{l}-0.100 \\
(0.136)\end{array}$ & $\begin{array}{l}-0.101 \\
(0.228)\end{array}$ & $\begin{array}{l}-0.093 \\
(0.252)\end{array}$ & $\begin{array}{l}-0.093 \\
(0.278)\end{array}$ & $\begin{array}{l}-0.094 \\
(0.263)\end{array}$ \\
\hline Fiscal balance & $\begin{array}{c}0.361^{* * *} \\
(0.000)\end{array}$ & $\begin{array}{c}0.444 * * * \\
(0.000)\end{array}$ & $\begin{array}{c}0.379 * * * \\
(0.001)\end{array}$ & $\begin{array}{c}0.341^{* * *} \\
(0.003)\end{array}$ & $\begin{array}{c}0.321 * * * \\
(0.006)\end{array}$ \\
\hline Health spending & $\begin{array}{c}-0.517 * * * \\
(0.001)\end{array}$ & $\begin{array}{c}-0.519 * * * \\
(0.006)\end{array}$ & $\begin{array}{c}-0.391 * * \\
(0.026)\end{array}$ & $\begin{array}{c}-0.397 * * \\
(0.024)\end{array}$ & $\begin{array}{c}-0.398 * * \\
(0.026)\end{array}$ \\
\hline FX intervention \# capital openness & $\begin{array}{c}0.162 \\
(0.403)\end{array}$ & $\begin{array}{c}0.311 \\
(0.180)\end{array}$ & $\begin{array}{c}0.236 \\
(0.296)\end{array}$ & $\begin{array}{c}0.045 \\
(0.842)\end{array}$ & $\begin{array}{l}-0.075 \\
(0.740)\end{array}$ \\
\hline Private credit & $\begin{array}{c}-0.023 * * * \\
(0.006)\end{array}$ & $\begin{array}{c}-0.031 \text { *** } \\
(0.001)\end{array}$ & $\begin{array}{c}-0.027 * * * \\
(0.003)\end{array}$ & $\begin{array}{c}-0.030^{* * * *} \\
(0.001)\end{array}$ & $\begin{array}{c}-0.029 * * * \\
(0.002)\end{array}$ \\
\hline \multicolumn{6}{|l|}{ Structural variables } \\
\hline Output per worker & $\begin{array}{c}0.017 \\
(0.533)\end{array}$ & $\begin{array}{c}0.030 \\
(0.413)\end{array}$ & $\begin{array}{c}0.082^{* *} \\
(0.018)\end{array}$ & $\begin{array}{c}0.104 * * * \\
(0.003)\end{array}$ & $\begin{array}{l}0.088^{* *} \\
(0.012)\end{array}$ \\
\hline Expected growth & $\begin{array}{c}-0.474 * * * \\
(0.001)\end{array}$ & $\begin{array}{c}-0.468 * * * \\
(0.005)\end{array}$ & $\begin{array}{c}-0.587 * * * \\
(0.000)\end{array}$ & $\begin{array}{c}-0.663^{* * * *} \\
(0.000)\end{array}$ & $\begin{array}{c}-0.682 * * * \\
(0.000)\end{array}$ \\
\hline NFA & $\begin{array}{c}0.017 * * \\
(0.011)\end{array}$ & $\begin{array}{c}0.020 * * * \\
(0.008)\end{array}$ & $\begin{array}{c}0.025^{* * * *} \\
(0.001)\end{array}$ & $\begin{array}{c}0.022 * * * \\
(0.003)\end{array}$ & $\begin{array}{l}0.018 * * \\
(0.017)\end{array}$ \\
\hline NFA highdebt & $\begin{array}{l}-0.012 \\
(0.427)\end{array}$ & $\begin{array}{l}-0.013 \\
(0.431)\end{array}$ & $\begin{array}{l}-0.022 \\
(0.173)\end{array}$ & $\begin{array}{l}-0.021 \\
(0.191)\end{array}$ & $\begin{array}{l}-0.014 \\
(0.377)\end{array}$ \\
\hline Oil/gas trade balance & $\begin{array}{c}0.395 \\
(0.103)\end{array}$ & $\begin{array}{l}0.547 * \\
(0.092)\end{array}$ & $\begin{array}{c}0.238 \\
(0.406)\end{array}$ & $\begin{array}{c}0.412 \\
(0.143)\end{array}$ & $\begin{array}{l}0.543^{*} \\
(0.060)\end{array}$ \\
\hline Old age dependency ratio & $\begin{array}{l}-0.038 \\
(0.540)\end{array}$ & $\begin{array}{l}-0.128 \\
(0.135)\end{array}$ & $\begin{array}{l}-0.142 * \\
(0.068)\end{array}$ & $\begin{array}{c}-0.260 * * * \\
(0.004)\end{array}$ & $\begin{array}{c}-0.199 * * \\
(0.029)\end{array}$ \\
\hline Population growth & $\begin{array}{l}-0.147 \\
(0.728)\end{array}$ & $\begin{array}{l}-0.061 \\
(0.896)\end{array}$ & $\begin{array}{c}0.077 \\
(0.862)\end{array}$ & $\begin{array}{l}-0.243 \\
(0.584)\end{array}$ & $\begin{array}{l}-0.073 \\
(0.874)\end{array}$ \\
\hline Rel. old age dependency ratio \# aging speed & $\begin{array}{c}0.147 * * * \\
(0.000)\end{array}$ & $\begin{array}{c}0.114^{* *} * \\
(0.015)\end{array}$ & $\begin{array}{l}0.081 * \\
(0.054)\end{array}$ & $\begin{array}{c}0.054 \\
(0.211)\end{array}$ & $\begin{array}{c}0.073 \\
(0.105)\end{array}$ \\
\hline Rel. aging speed \# old age dependency ratio & $\begin{array}{c}0.044 \\
(0.383)\end{array}$ & $\begin{array}{c}0.095 \\
(0.260)\end{array}$ & $\begin{array}{c}0.089 \\
(0.237)\end{array}$ & $\begin{array}{c}0.202 * * \\
(0.016)\end{array}$ & $\begin{array}{l}0.186^{* *} \\
(0.029)\end{array}$ \\
\hline Financial center & $\begin{array}{c}0.023 * * * \\
(0.005)\end{array}$ & $\begin{array}{c}0.020^{* *} \\
(0.015)\end{array}$ & $\begin{array}{c}0.028 * * * \\
(0.000)\end{array}$ & $\begin{array}{c}0.032 * * * \\
(0.000)\end{array}$ & $\begin{array}{c}0.033 * * * \\
(0.000)\end{array}$ \\
\hline Safe institutions & $\begin{array}{c}-0.112^{* * *} \\
(0.000)\end{array}$ & $\begin{array}{c}-0.135^{* * *} \\
(0.000)\end{array}$ & $\begin{array}{c}-0.128 * * * \\
(0.000)\end{array}$ & $\begin{array}{c}-0.118^{* * *} * \\
(0.000)\end{array}$ & $\begin{array}{c}-0.114 * * * \\
(0.000)\end{array}$ \\
\hline Reserve currency & $\begin{array}{c}-0.052 * * * \\
(0.000)\end{array}$ & $\begin{array}{c}-0.069^{* * *} \\
(0.000)\end{array}$ & $\begin{array}{c}-0.066^{* * *} \\
(0.000)\end{array}$ & $\begin{array}{c}-0.075^{* * *} * \\
(0.000)\end{array}$ & $\begin{array}{c}-0.076^{* * * *} \\
(0.000)\end{array}$ \\
\hline \multicolumn{6}{|l|}{ Sectoral structure variables } \\
\hline Producer services share $(t+1)$ & & & $\begin{array}{c}-0.062^{* * *} \\
(0.001)\end{array}$ & $\begin{array}{l}-0.054 * * * \\
(0.004)\end{array}$ & $\begin{array}{l}-0.036^{*} \\
(0.070)\end{array}$ \\
\hline Consumer services share $(t+1)$ & & & $\begin{array}{l}-0.017 \\
(0.183)\end{array}$ & $\begin{array}{c}-0.034 * * \\
(0.018)\end{array}$ & $\begin{array}{c}0.015 \\
(0.449)\end{array}$ \\
\hline Production share $(t+1)$ & & & $\begin{array}{c}0.032 * * \\
(0.035)\end{array}$ & $\begin{array}{c}0.008 \\
(0.648)\end{array}$ & $\begin{array}{l}-0.016 \\
(0.444)\end{array}$ \\
\hline Producer services share \# Production Domar $(t+1)$ & & & & $\begin{array}{c}-0.136 * * * \\
(0.001)\end{array}$ & $\begin{array}{l}-0.114 * * * \\
(0.006)\end{array}$ \\
\hline Producer services share \# Comsumer services Domar $(t+1)$ & & & & $\begin{array}{c}-0.178^{* *} \\
(0.014)\end{array}$ & $\begin{array}{c}-0.190^{* *} \\
(0.011)\end{array}$ \\
\hline Production Domar $(t+1)$ & & & & & $\begin{array}{c}0.033^{* *} \\
(0.025)\end{array}$ \\
\hline Consumer services Domar $(t+1)$ & & & & & $\begin{array}{c}-0.060 * * * \\
(0.000)\end{array}$ \\
\hline Final goods Domar $(t+1)$ & & & & $\begin{array}{c}0.002 \\
(0.855)\end{array}$ & \\
\hline Constant & $\begin{array}{c}-0.014 * * * \\
(0.000)\end{array}$ & $\begin{array}{c}-0.017 * * * \\
(0.000)\end{array}$ & $\begin{array}{c}-0.022 * * * \\
(0.000)\end{array}$ & $\begin{array}{c}-0.025 * * * \\
(0.000)\end{array}$ & $\begin{array}{c}-0.021 * * * \\
(0.000)\end{array}$ \\
\hline Observations & 1,001 & 669 & 669 & 669 & 669 \\
\hline R-squared & 0.517 & 0.609 & 0.662 & 0.686 & 0.692 \\
\hline Number of IMFCodes & 40 & 40 & 40 & 40 & 40 \\
\hline Adj. R-squared & 0.507 & 0.596 & 0.649 & 0.673 & 0.679 \\
\hline Root MSE & 0.031 & 0.030 & 0.028 & 0.027 & 0.027 \\
\hline
\end{tabular}

$\mathrm{P}$-values of heteroscedasticity-corrected $\mathrm{z}$-statistics in parentheses

$* * * \mathrm{p}<0.01, * * \mathrm{p}<0.05, * \mathrm{p}<0.1$ 
Table 8: EBA Current Account Gaps and Residuals (in \% of GDP)

\begin{tabular}{|c|c|c|c|c|c|c|c|c|}
\hline & \multicolumn{4}{|c|}{ Standard Specification } & \multicolumn{4}{|c|}{ Extended Specification } \\
\hline & Gap & Policy Gap & Residual & Cyclical & Gap & Policy Gap & Residual & Cyclical \\
\hline ARG & 3.18 & 4.01 & 1.98 & 0.99 & 1.90 & 2.00 & 1.45 & 0.95 \\
\hline AUS & 3.63 & 1.26 & 4.89 & 0.48 & 2.58 & 1.00 & 3.55 & 0.45 \\
\hline AUT & 1.92 & 2.16 & 3.43 & 0.51 & 2.23 & 0.95 & 2.74 & 0.48 \\
\hline BEL & 1.11 & 0.55 & 1.08 & 0.34 & 2.67 & 0.31 & 2.62 & 0.32 \\
\hline BRA & 3.00 & 2.59 & 1.44 & 0.95 & 2.80 & 1.11 & 1.91 & 0.91 \\
\hline CAN & 1.94 & 1.58 & 2.45 & 0.53 & 1.73 & 1.14 & 2.22 & 0.50 \\
\hline CHE & 3.29 & 1.79 & 3.08 & 0.53 & 3.04 & 1.13 & 2.94 & 0.50 \\
\hline CHL & 5.95 & 4.30 & 2.29 & 0.55 & 4.55 & 2.55 & 2.41 & 0.46 \\
\hline $\mathrm{CHN}$ & 6.15 & 5.92 & 3.34 & 1.49 & 3.96 & 1.02 & 3.79 & 1.41 \\
\hline $\mathrm{COL}$ & 2.70 & 1.90 & 4.37 & 1.04 & 1.77 & 0.80 & 2.52 & 1.00 \\
\hline CRI & 2.07 & 1.96 & 1.42 & 1.38 & 2.17 & 1.36 & 1.57 & 1.32 \\
\hline CZE & 2.54 & 0.79 & 2.52 & 1.57 & 2.67 & 0.41 & 2.67 & 1.49 \\
\hline DEU & 4.01 & 1.27 & 3.83 & 0.59 & 2.87 & 0.73 & 2.48 & 0.56 \\
\hline DNK & 3.03 & 1.94 & 1.77 & 0.35 & 3.39 & 1.28 & 2.23 & 0.33 \\
\hline ESP & 1.94 & 1.94 & 2.05 & 1.33 & 1.95 & 1.22 & 2.23 & 1.27 \\
\hline FIN & 5.21 & 2.80 & 3.42 & 0.69 & 4.02 & 1.74 & 3.03 & 0.66 \\
\hline FRA & 0.80 & 0.60 & 0.78 & 0.24 & 0.82 & 0.20 & 0.96 & 0.23 \\
\hline GBR & 2.11 & 1.98 & 1.17 & 0.30 & 1.10 & 1.14 & 1.01 & 0.29 \\
\hline GRC & 4.10 & 2.42 & 2.52 & 2.35 & 2.43 & 1.22 & 1.70 & 2.25 \\
\hline HUN & 2.62 & 3.21 & 2.77 & 1.25 & 2.85 & 1.72 & 2.46 & 1.19 \\
\hline IND & 3.30 & 1.32 & 2.09 & 0.62 & 1.31 & 0.47 & 1.49 & 0.59 \\
\hline IRL & 2.36 & 2.58 & 1.18 & 1.55 & 2.27 & 1.61 & 1.81 & 1.48 \\
\hline ISR & 2.15 & 1.21 & 1.27 & 0.97 & 2.03 & 0.66 & 1.36 & 0.92 \\
\hline ITA & 1.55 & 0.63 & 1.45 & 0.47 & 0.90 & 0.34 & 1.04 & 0.45 \\
\hline JPN & 2.08 & 2.02 & 1.17 & 0.58 & 1.54 & 1.13 & 0.94 & 0.55 \\
\hline KOR & 3.90 & 3.00 & 1.08 & 0.54 & 2.23 & 1.53 & 0.83 & 0.51 \\
\hline MAR & 2.19 & 2.75 & 2.05 & 0.92 & 1.93 & 0.74 & 1.93 & 0.87 \\
\hline MYS & 10.79 & 2.35 & 8.76 & 0.26 & 5.36 & 0.77 & 4.92 & 0.25 \\
\hline NLD & 2.83 & 1.60 & 2.73 & 1.01 & 2.97 & 1.27 & 2.65 & 0.97 \\
\hline NZL & 2.62 & 1.33 & 3.71 & 1.04 & 2.15 & 0.94 & 2.77 & 0.99 \\
\hline PER & 2.67 & 1.89 & 2.13 & 0.63 & 1.66 & 1.18 & 1.51 & 0.59 \\
\hline PHL & 3.31 & 1.63 & 1.93 & 0.39 & 3.33 & 0.85 & 2.51 & 0.37 \\
\hline POL & 1.60 & 0.54 & 1.56 & 0.74 & 1.66 & 0.39 & 1.68 & 0.70 \\
\hline PRT & 4.11 & 2.43 & 2.12 & 0.68 & 3.42 & 1.30 & 2.57 & 0.65 \\
\hline SWE & 7.69 & 2.21 & 5.53 & 0.46 & 6.28 & 1.48 & 4.82 & 0.43 \\
\hline THA & 4.66 & 3.92 & 2.50 & 0.85 & 2.13 & 1.40 & 2.42 & 0.81 \\
\hline TUN & 1.77 & 2.63 & 1.70 & 0.95 & 1.77 & 0.90 & 1.42 & 0.90 \\
\hline TUR & 2.42 & 1.77 & 3.04 & 1.06 & 1.50 & 1.16 & 2.23 & 1.00 \\
\hline USA & 2.06 & 1.11 & 1.63 & 0.52 & 2.23 & 0.55 & 1.86 & 0.50 \\
\hline ZAF & 1.50 & 2.86 & 2.76 & 0.34 & 1.39 & 1.26 & 1.33 & 0.33 \\
\hline (Unweighted) & & & & & & & & \\
\hline Sample average & 3.13 & 2.05 & 2.50 & 0.79 & 2.49 & 1.05 & 2.21 & 0.75 \\
\hline
\end{tabular}

All values are calculated in absolute terms over the sample period given availability of the data. 